\title{
Материалы к изучению фауны наземных позвоночных Каменной степи (Таловский район, Воронежская область)
}

\author{
А.Д. Нумеров, А.С. Климов, Е.И. Труфанова \\ Воронежский государственный университет, \\ Россия, 394006, г. Воронеж, Университетская пл., 1 \\ E-mail: anumerov@yandex.ru; as_klimov@mail.ru; eitrufanova@yandex.ru
}

\begin{abstract}
Аннотация. В результате наблюдений, учётов и специальных обследований на территории (акватории) Каменной степи (Таловский район, Воронежская область) в июне 2018 г. и июне 2019 г. зарегистрировано 6 видов земноводных 2 отрядов, 4 вида пресмыкающихся 3 отрядов, 76 видов птиц 15 отрядов и 23 вида млекопитающих 3 отрядов. Отмечены некоторые изменения в фауне лесных насаждений за 20-50 лет. Из состава гнездящихся видов птиц лесополос исчезли грач, обыкновенная сорока, ушастая сова, обыкновенная пустельга. Не отмечены такие ранее обычные виды, как серая куропатка, фазан, коростель, чернолобый сорокопут и болотная камышёвка. Среди новых гнездящихся видов Каменной степи зарегистрированы серая цапля, белокрылая крачка, а также, с большой вероятностью, сирийский дятел и удод. Акустический мониторинг позволил установить пребывание на территории Каменной степи не менее 12 видов рукокрылых.
\end{abstract}

Ключевые слова: Каменная степь, лесополосы, наземные позвоночные, земноводные, пресмыкающиеся, птицы, млекопитающие.

Для цитирования: Нумеров А.Д., Климов А.С., Труфанова Е.И. 2021. Материалы к изучению фауны наземных позвоночных Каменной степи (Таловский район, Воронежская область). Полевой журнал биолога, 3 (1): 25-52. DOI: 10.52575/2658-3453-2021-3-1-25-52

\section{Materials for Studying of the Fauna of Terrestrial Vertebrates of the Kamennaya Step' (Talovskiy District, Voronezh Region, Russia)}

\author{
Alexander D. Numerov, Alexander S. Klimov, Elena I. Trufanova \\ Voronezh State University, \\ Universitetskaya Sq, Voronezh, 394006, Russian Federation \\ E-mail: anumerov@yandex.ru; as_klimov@mail.ru; eitrufanova@yandex.ru
}

\begin{abstract}
The data of a zoological survey of the Kamennaya Step' (Talovskiy District of the Voronezh Region) in June 2018 and June 2019 are presented. As a result of observations, counts and special surveys on the territory (water area) of the Kamennaya Step', 6 species of amphibians of 2 orders, 4 species of reptiles of 3 orders, 76 species of birds of 15 orders and 23 species of mammals of 3 orders were registered. Some changes have been noted in the composition of the fauna of forest plantations over the past 20-50 years. From the composition of nesting species of birds, forest belts have disappeared rook, magpie, long-eared owl, kestrel. Previously common species such as the partridge, pheasant, corncrake, lesser grey shrike and marsh warbler were not noted. Among the new nesting species of the Kamennaya Step', the common heron, the white-winged black tern, and also the Syrian woodpecker and the hoopoe, are most likely. Acoustic monitoring made it possible to establish the presence of at least 12 species of bats on the territory of the Kamennaya Step'.
\end{abstract}


Keywords: Kamennaya Step', forest belts, terrestrial vertebrates, amphibians, reptiles, birds, mammals.

For citation: Numerov A.D., Klimov A.S., Trufanova E.I. 2020. Materials for Studying of the Fauna of Terrestrial Vertebrates of the Kamennaya Step' (Talovskiy District, Voronezh Region, Russia). Field Biologist Journal, 3 (1): 25-52. (In Russian.) DOI: 10.52575/2658-3453-2021-3-1-25-52

\section{Введение}

Каменная степь - историческое название территории, расположенной на границе между степью и лесостепью на водоразделе двух рек - Чиглы (приток р. Битюг) и Елани (приток р. Хопёр). Первые упоминания участка с таким названием (между р. Чиглой и p. Сухой Чиглой) мы находим в публикациях середины XIX века. Изучение фауны наземных позвоночных данной территории имеет более чем полуторавековую историю. В 1850 г., то есть до преобразования степей Воронежской губернии, здесь исследовал фауну выдающийся зоолог и путешественник Н.А. Северцов. В то время под Каменной степью он подразумевал весь водораздел между реками Битюг и Хопёр. В монографии «Периодические явления в жизни зверей, птиц и гад Воронежской губернии» (1-е изд. в 1855 г., 2-е изд. в 1950 г.) Н.А. Северцов приводит 45 видов птиц, характерных для прежней Каменной степи, из них - 17 гнездящихся в самой степи [Северцов, 1950].

В 1892 году под руководством В.В. Докучаева в Каменной степи начала работать комплексная «Особая экспедиция лесного департамента Министерства земледелия и государственных имуществ по испытанию и учету различных способов и приёмов лесного и водного хозяйства в степях России», тогда были заложены первые лесные полосы. Участником этой экспедиции был А.А. Силантьев, который в период 1894-1896 гг. проводил здесь зоологические исследования. На этой территории степи им было зарегистрировано 5 видов земноводных, 2 вида пресмыкающихся, 26 видов птиц и 14 видов млекопитающих [Силантьев, 1898].

Позднее работу по созданию лесных насаждений выполняли сотрудники КаменноСтепного опытного лесничества (1894-1907 гг.). Формирование общей структуры и возрастные изменения лесополос стали привлекать различные виды птиц и млекопитающих, параллельно с этим началось их изучение. В 1921-1922 гг. здесь работала экспедиция Московского университета под руководством С.И. Огнева, с участием К.А. Воробьева, В.Г. Гептнера, И.В. Шибанова, А.И. Юрина. Они впервые дали описание преобразованной фауны, отметив богатство птичьего населения лесополос [Огнев, Воробьёв, 1923]. В 1932 г. на территории Каменной степи работала экспедиция Всесоюзного института защиты растений под руководством С.И. Оболенского, с участием А.Б. Кистяковского, В.И. Львовой и др. Задачей этой экспедиции было изучение экологии грызунов, а также видового состава и хозяйственного значения птиц. Последнее входило в обязанности А.Б. Кистяковского, который уже в 1932 г. отметил в лесных полосах 31 вид гнездящихся птиц, обратил внимание на малочисленность дуплогнёздников, отсутствие типичных лесных обитателей среди гнездящихся видов, исследовал способы привлечения птиц [Кистяковский, 1935].

Изучение орнитофауны, начиная с 1930-х годов, стало одним из основных направлений исследований позвоночных животных. В научном отчете за 1949 г. Е.А. Тарановский приводит видовой состав птиц Каменной степи, включающий 103 вида гнездящихся птиц, а с пролётными и зимующими - 178 видов (эти данные относятся к птицам всего комплекса полос и межполосных участков). В 1950 г. орнитофауна полезащитных лесных полос Каменной степи по данным наблюдений С.Н. Марина включала 
73 вида птиц, из них 46 видов (63 \%) отмечены как гнездящиеся, 10 видов - как осёдлые [Марин, 1951]. С середины 1950-х годов изучение орнитофауны комплекса полезащитных лесных полос и межполосных участков юго-востока Чернозёмного центра (на примере Каменной степи) проводил Л.Л. Семаго. Им было зарегистрировано здесь 137 видов птиц, в том числе 67 гнездящихся видов [Семаго, 1954, 1960, 1970]. В 1970 г. Л.В. Куликовой было зарегистрировано 60 видов птиц 13 отрядов во время обследования и картирования птичьего населения лесных полос Каменной степи [Куликова, 1971]. Фауну хищных птиц и сов Каменной степи и влияние параметров лесополос на их расселение в 1989-1991 гг. изучал В.Г. Турчин [1991, 1994, 1996, 1999а, б]. В общем аннотированном списке видов Каменной степи он упоминает 135 видов птиц [Турчин, 2000].

Позднее, в течение полевых сезонов 1996-1997 гг. на территории Каменной степи изучение орнитофауны лесополос проводила С.В. Тунякина. Установлено пребывание в гнездовой период 32 видов, а зимой - 14 видов птиц [Тунякина, 1998]. В 2007 г. численность и распределение по территории хищных птиц и ворона изучал С.Ф. Сапельников [2010]. В апреле - июне 2011 г. П.Д. Венгеровым и А.А. Рубан [2011] проведены учёты гнездящихся птиц в лесополосах № 40-43. Всего зарегистрировано 33 вида.

Фауну млекопитающих наиболее подробно изучали в второй половине XIX и начале XX веков [Северцов, 1950; Силантьев, 1898; Огнев, Воробьёв, 1923]. Позднее, в 19501951 гг., В.Н. Александровым под руководством И.И. Барабаш-Никифорова в Каменной степи были проведены исследования по выяснению размещения и оценке численности сурков-байбаков в поселениях, которые здесь все еще сохранялись благодаря охране [Александров, 1951; Барабаш-Никифоров, Александров, 1953; Барабаш-Никифоров, 1957]. В 1990 г. при изучении особенностей питания ушастых сов были проведены небольшие исследования и по фауне мелких млекопитающих. В рационе сов были обнаружены 9 видов грызунов и 1 вид насекомоядных [Турчин, Борискина, 1996].

В последующие годы специальных зоологических исследований на территории Каменной степи не проводилось. Отдельные кратковременные посещения территории осуществлялись во время экспедиционных выездов с целью подготовки второго издания Красной книги Воронежской области [2018]. Столь значительный перерыв в наблюдениях за изменениями фауны Каменной степи, происходящих под влиянием естественных сукцессий лесополос и погодно-климатических факторов последних десятилетий, побудил нас к проведению зоологического обследования этой территории.

\section{Характеристика района исследования}

Сегодня территория Каменной степи входит в состав комплексного государственного природного заказника федерального значения с одноимённым названием. Заказник был создан в 1996 г. для охраны исторически сложившихся уникальных полукультурных лесостепных ландшафтов, образованных сложным комплексом сельскохозяйственных полей, старовозрастных лесополос, косимых и некосимых залежей и заросших лесом балок. С 2009 г. территория находится в оперативном управлении Воронежского государственного природного биосферного заповедника имени В.М. Пескова.

По административно-территориальному делению Каменная степь находится в Таловском районе Воронежской области. Основным элементом, формирующим общий облик ландшафта Каменной степи, являются многочисленные лесные полосы, которые образуют сложную систему лесонасаждений, различающихся по видовому составу, ширине, протяженности, возрасту. Каждая лесополоса уникальна. Это настоящие многоярусные лесные сообщества. Верхний ярус состоит из дуба, клёна, ясеня, под ними располагаются липа, яблоня, груша, а ещё ниже - лещина, черёмуха, акация. У самой земли - подрост деревьев и кустарники: бересклет, жимолость и крушина. Лесополосы ограничивают много- 
численные сельскохозяйственные поля, засаженные кукурузой, подсолнечником и различными зерновыми культурами.

В настоящее время Каменная степь - это экологически сбалансированный лесопольный комплекс с разветвлённой системой водосберегающих сооружений. Наиболее крупными искусственными водоёмами являются верхнее водохранилище (Докучаевское море, с 1950 г.) и нижнее (Таловский пруд), протяжённостью около 8 км.

Посёлок 2-го участка Научно-исследовательского института сельского хозяйства Центрально-Чернозёмной полосы имени В.В. Докучаева (НИИСХ ЦЧП) представляет собой поселение сельского типа с численностью населения около 4,5 тыс. человек, вытянутое в длину на 2,5 км и в ширину от 400 м до 1,0 км. Застроен в основном одноэтажными домами с многочисленными подсобными хозяйственными строениями на подворьях, а также двух- и пятиэтажными жилыми и служебными зданиями. В центре посёлка расположен небольшой парк (около 4 га). Посёлок со всех сторон окружён сельскохозяйственными полями и сложной сетью разнообразных лесных полос.

\section{Материал и методы исследования}

Исследования проводились с 21 по 27 июня 2018 г. и с 19 по 26 июня 2019 г. на территории комплексного государственного природного заказника федерального значения «Каменная степь» (площадь 5232 га), включая окрестности и сам посёлок 2-го участка НИИСХ ЦЧП. Зоологические экскурсии, специальные наблюдения и учёты наземных позвоночных в лесополосах и на других участках заказника проводили ежедневно.

Мелких млекопитающих учитывали стандартным методом отлова ловушкамидавилками, которые в количестве 50 штук выставляли на ночь в линии с интервалом в 5 м между соседними. В качестве приманки использовали кусочки слегка подсушенного хлеба $\left(1 \mathrm{~cm}^{3}\right)$, смоченного подсолнечным маслом. Всего проведено 7 учётов (400 ловушко-ночей в лесополосах № 34, 40 и 127), поймано 64 экз. 4 видов грызунов и 2 видов насекомоядных.

Видовой состав рукокрылых (Chiroptera) определяли при помощи ультразвукового детектора Echo Meter Touch 2 PRO, записывающего и определяющего до вида ультразвуковые сигналы мышей. Учёт голосов летучих мышей проводили 20-24 июня 2019 г. в посёлке 2-го участка НИИСХ ЦЧП и в его окрестностях. Два учёта были проведены на краю скошенного разнотравного участка, тянущегося вдоль восточной опушки лесополос № 40 и 127, один - на поле в промежутке между лесополосой № 40 и началом лесополосы № 34 и один - в самом посёлке. Общая продолжительность учётов составила около 6,6 часов (395 минут). Был также заложен один пеший маршрут протяжённостью в 1 км. Всего было зафиксировано 304 ультразвуковых сигнала летучих мышей, из которых видовая принадлежность была определена для 189 (62,3 \%). За время наблюдений были записаны ультразвуковые сигналы 12 видов летучих мышей.

Данные по птицам получены в результате наблюдений и обследования лесополос № 33, 34, 40, 71, 127, 138, 155, 156 и 160, парка в посёлке института, прудов и водохранилища. Наблюдения проводили с 7 до 11 часов и с 16 до 21 часа. Суммарная протяжённость ежедневных маршрутов составляла 10-12 км. Всего зарегистрировано 76 видов, относящихся к 15 отрядам.

Систематика земноводных и пресмыкающихся приведена по атласу «Земноводные и пресмыкающиеся России» [Дунаев, Орлова, 2017] с уточнениями по систематике чесночницы [Литвинчук и др., 2008]. Русские и латинские названия птиц, а также систематика приведены по «Списку птиц Российской Федерации» [Коблик и др., 2006], млекопитающих - по справочнику «Млекопитающие России» [Павлинов, Лисовский, 2012]. 


\section{Результаты и их обсуждение}

В результате проведенных в 2018-2019 гг. наблюдений, учётов и обследований на территории (акватории) Каменной степи установлено пребывание видов наземных позвоночных животных, аннотированный список которых приводится ниже.

\section{Класс Amphibia - Земноводные \\ Отряд Caudata - Хвостатые}

1. Lissotriton vulgaris (Linnaeus, 1758) - обыкновенный тритон.

Вероятно, данный вид довольно обычен в водоёмах обследованного района. На его присутствие здесь указывал еще в начале прошлого века С.И. Огнев, находивший тритонов как в нижнем, так и верхнем Хорольских прудах [Огнев, Воробьёв, 1923]. Нами специальных поисков и отловов данного вида не предпринималось. Однако 23.06.2018 взрослый самец обыкновенного тритона был отловлен случайно сачком в небольшом пруду (около 40 м в поперечнике) на северной окраине посёлка 2-го участка НИИСХ ЦЧП (рис. 1).

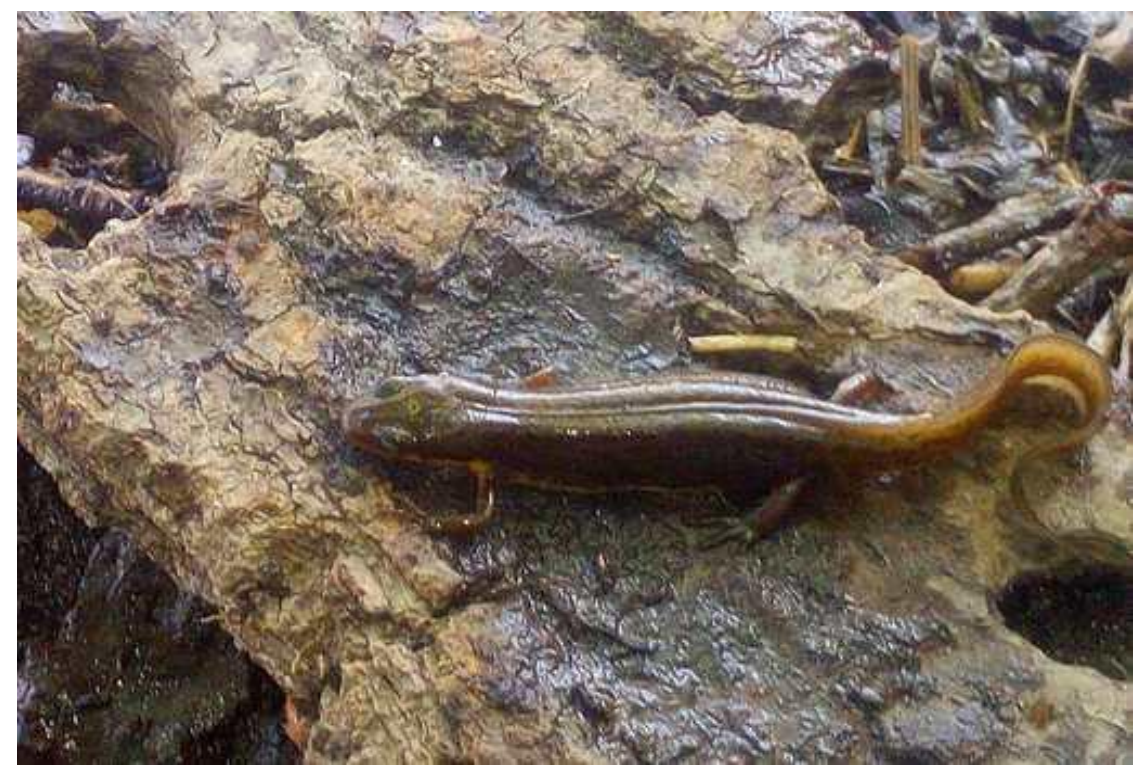

Рис. 1. Тритон обыкновенный, Lissotriton vulgaris (Linnaeus, 1758), самец, территория комплексного государственного природного заказника «Каменная степь», пруд на северной окраине посёлка 2-го участка Научно-исследовательского института сельского хозяйства имени В.В. Докучаева, 23.06.2018 (фото А.С. Климова)

Fig. 1. Common newt Lissotriton vulgaris (Linnaeus, 1758), male, territory of complex state nature reserve "Kamennaya Step'", pond on northern vicinity of village of $2^{\text {nd }}$ section of Scientific Research

Institute of Agriculture named after V.V. Dokuchaev, 23.06.2018 (photo by A. Klimov)

\section{Отряд Anura - Бесхвостые}

2. Bombina bombina (Linnaeus, 1761) - краснобрюхая жерлянка.

По-видимому, как и везде по Воронежской области, в Каменной степи обычный, но немногочисленный вид. Нам удалось 23.06.2018 слышать редкие крики жерлянок в трёх небольших прудах, расположенных на правом берегу в верховьях Докучаевского моря.

3. Pelobates vespertinus (Pallas, 1771) - чесночница Палласа.

Обычный немногочисленный вид Каменной степи. В том же пруду, где был отловлен тритон, 23.06.2018 были обнаружены и головастики чесночницы. Крупная взрослая чесночница была встречена поздно вечером 24.06.2018 на краю поля, засеянного подсолнечником, между лесополосами № 34 и 40. Здесь же 23.06.2019 были найдены на дороге 2 молодые чесночницы, погибшие под колесами автотранспорта. 
4. Bufotes viridis (Laurenti, 1768) - зелёная жаба.

Один из наиболее обычных представителей амфибий Каменной степи. В 2018 г. в посёлке 2-го участка НИИСХ ЦЧП за время пребывания были встречены 6 взрослых особей и найдены останки нескольких животных, погибших под колёсами автотранспорта на дорогах. Также 23.06.2018 нами наблюдался массовый выход на сушу закончивших метаморфоз зелёных жабят на отмелях левого берега в верховьях водохранилища. На одном участке береговой полосы, протяжённостью около 30-50 м, при приближении к урезу воды сотни сеголеток размером около 1,5 см перемещались из-под ног в разные стороны. Расстояние между соседними особями в этой движущейся массе было не более 10-15 см. В 2019 г. на дорогах посёлка были встречены останки 7 зелёных жаб, погибших под колесами автотранспорта.

5. Pelophylax ridibundus (Pallas, 1771) - озёрная лягушка.

Озёрная лягушка довольно обычна, хотя и немногочисленна в водоёмах Каменной степи. Отдельные особи были нами встречены на водохранилище и в некоторых окрестных прудах. Один недавно метаморфизировавший сеголеток размером не более 8-9 мм был отловлен 23.06.2018 в небольшом пруду на северной окраине посёлка.

6. Rana arvalis Nilsson, 1842 - остромордая лягушка.

Из-за относительной засушливости местных климатических условий, это, скорее всего, немногочисленный вид местной фауны. Нами был встречен всего один экземпляр сеголетка остромордой лягушки вечером 20.06.2019 в лесополосе № 127.

\section{Класс Reptilia - Пресмыкающиеся \\ Отряд Testudines - Черепахи}

1. Emys orbicularis (Linnaeus, 1758) - болотная черепаха.

Данный вид нами не был обнаружен. Хотя, судя по наличию вполне подходящих для обитания стаций в нескольких окрестных прудах, болотная черепаха здесь вполне может жить. Это подтверждает сообщение местного жителя, встретившего в начале июня 2019 г. крупную черепаху примерно в 80 м от берега Таловского пруда.

Отряд Lacertilia - Ящерицы

2. Lacerta agilis Linnaeus, 1758 - прыткая ящерица.

Обычный, местами многочисленный вид. Ящерицы встречались повсеместно, хотя не часто. Чаще всего их можно было обнаружить на залежных участках и по заросшим травой берегам водохранилища и окрестных прудов.

\section{Отряд Serpentes - Змеи}

3. Natrix natrix (Linnaeus, 1758) - обыкновенный уж.

Обычный, хотя и немногочисленный вид. Нами 23.06.2018 была встречена одиночная особь в зарослях травы на берегу водохранилища, а 20.06.2019 были найдены останки ужа, раздавленного автомашиной на дороге при въезде в посёлок.

4. Pelias nikolskii (Vedmederja, Grubant, Rudaeva, 1986) - гадюка Никольского, или лесостепная гадюка.

По-видимому, изредка встречается по лесополосам Каменной Степи. Так, 20.06.2019 при маршрутном обследовании старовозрастной лесополосы № 34 была встречена взрослая чёрная гадюка.

\section{Класс Aves - Птицы}

Отряд Podicipediformes - Поганкообразные

1. Podiceps nigricollis C.L. Brehm, 1831 - черношейная поганка.

Две пары зарегистрированы на водохранилище 23.06.2018 около редких зарослей тростника. Одиночная птица отмечена на водохранилище 26.06.2018 во время обследования колоний белокрылых крачек и чомги. В 2019 г. одиночную птицу встретили в верховьях водохранилища. 
2. Podiceps cristatus (Linnaeus, 1758) - чомга.

При обследовании водохранилища 26.06.2018 обнаружена небольшая колония из 5-6 пар (рис. 2-3).

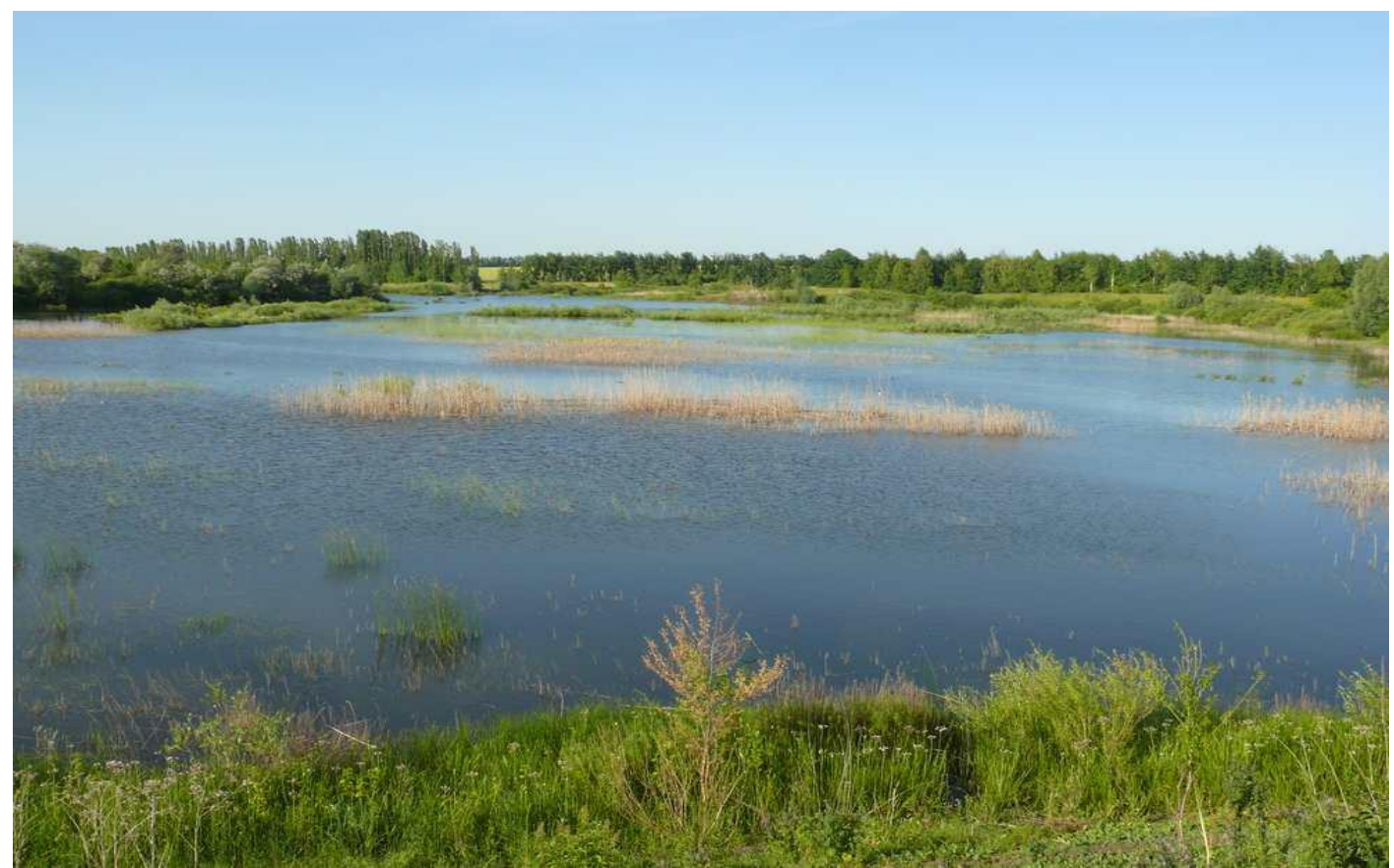

Рис. 2. Общий вид акватории с колониями чомги и крачек на водохранилище, территория комплексного государственного природного заказника «Каменная степь», 26.06.2018 (фото А.Д. Нумерова)

Fig. 2. General view of water area with colonies of great crested grebe and terns on the reservoir, territory of complex state nature reserve "Kamennaya Step", 26.06.2018 (photo by A. Numerov)
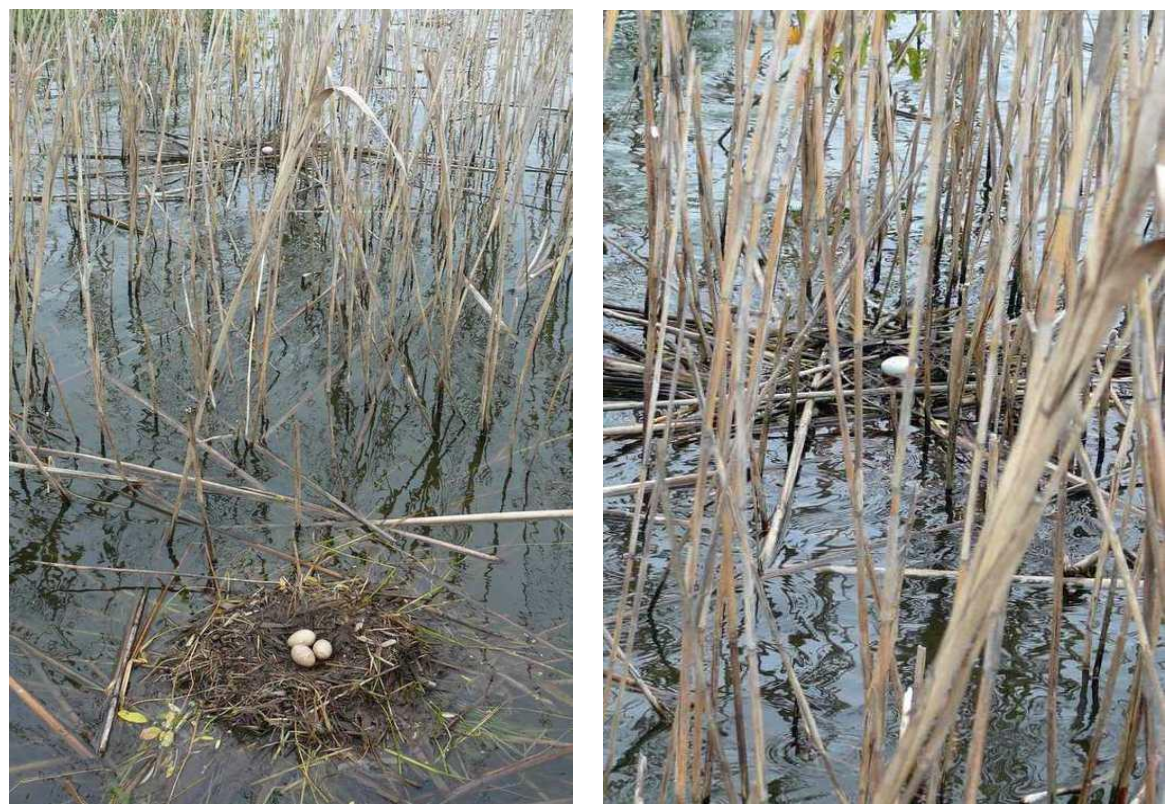

Рис. 3. Гнёзда чомги с кладками на водохранилище, территория комплексного государственного природного заказника «Каменная степь», 26.06 .2018 (фото А.Д. Нумерова)

Fig. 3. Nests of great crested grebe with clutches on the reservoir, territory of complex state nature reserve "Kamennaya Step'", 26.06.2018 (photo by A. Numerov) 
Осмотрено 4 гнезда: три гнезда с 3 и одно гнездо с 4 яйцами. Средняя кладка 3,25 яйца на гнездо, средний размер яиц 54,4 мм × 35,9 мм $(\mathrm{n}=13)$. У некоторых пар птенцы уже вылупились и плавали вместе со взрослыми птицами. Одна мёртвая взрослая особь без головы обнаружена в воде у берега. В 2019 г. акватория данного участка водохранилища заросла тростником и осокой (рис. 4), и группировка чомг из этого места исчезла.

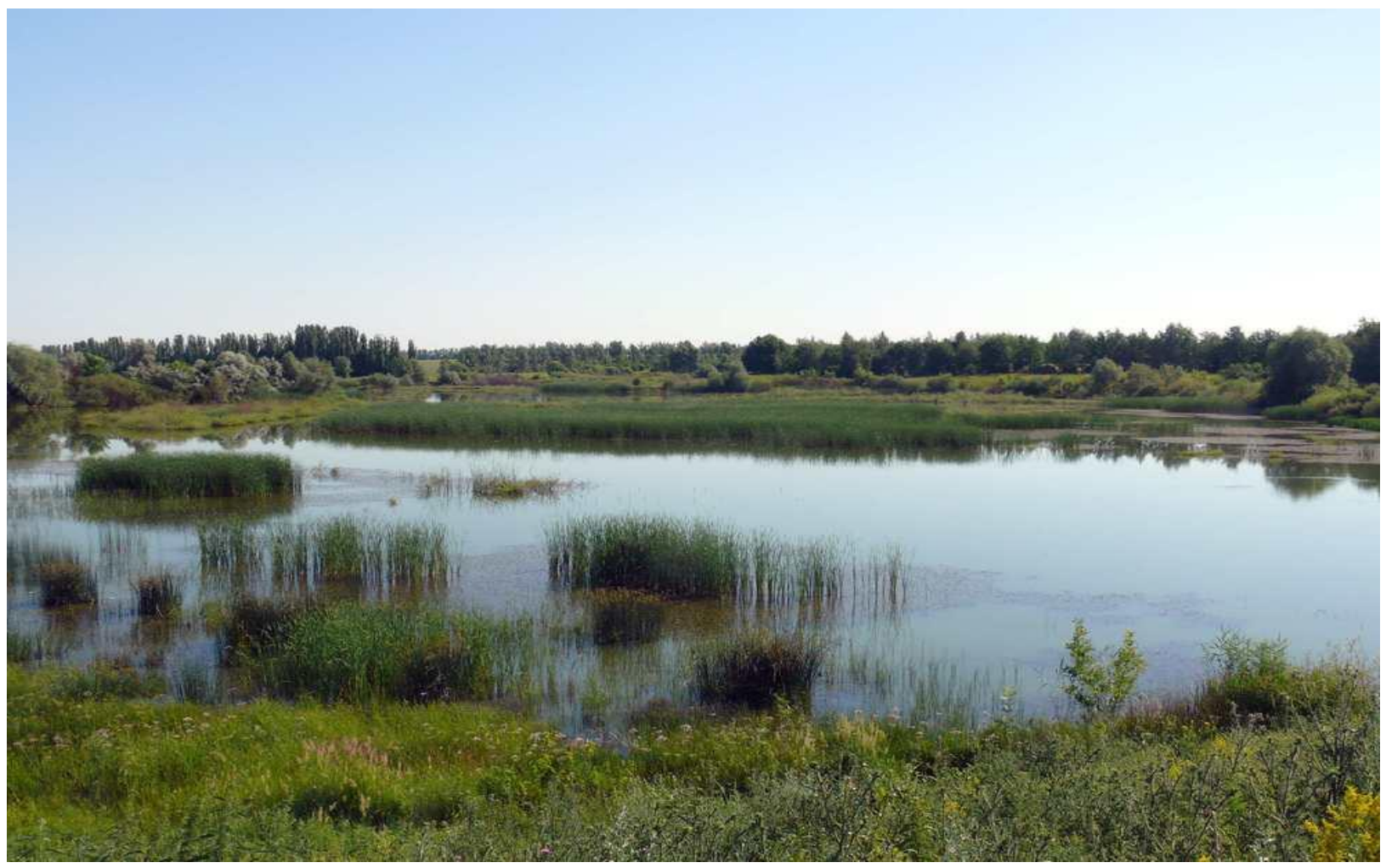

Рис. 4. Общий вид на участок акватории водохранилища в июне 2019 г., территория комплексного государственного природного заказника «Каменная степь» (фото А.Д. Нумерова)

Fig. 4. General view of the section of the reservoir in June 2019, territory of complex state nature reserve "Kamennaya Step'" (photo by A. Numerov)

Взрослые птицы (не менее 9 особей) с выводками (2, 3 и 4 птенца) встречены недалеко от плотины 22 и 23 июня. Одна птица сидела на гнезде (вероятно, на кладке). В маленьких затонах и заводях по левому берегу водохранилища встречены еще 3 пары поганок. Таким образом, общая численность чомг составляет не менее 10 пар.

\section{Отряд Ciconiiformes - Аистообразные}

3. Ixobrychus minutus (Linnaeus, 1766) - волчок.

В 1980-х годах отмечался как обычный вид, гнездящийся в зарослях камыша на водохранилище [Турчин, 1999а]. Нами этот вид отмечен только однажды (26.06.2018), хотя водохранилище мы посещали 4 раза и проводили по 2-3 часа наблюдений.

4. Ardea cinerea Linnaeus, 1758 - серая цапля.

Колония серых цапель (не менее 20 жилых гнезд) расположена в лесополосе № 71, примыкающей к водохранилищу (рис. 5). На момент осмотра (22.06.2018 и 26.06.2018) в гнёздах находилось по 2-3 взрослых птенца. В 2019 г. численность гнездящихся серых цапель существенно не изменилась. Собирающие корм взрослые цапли встречены по мелководьям всей акватории водохранилища. На пересыхающем Железняковском пруду 22.06.2018 встречены две кормящиеся особи. 


\section{Отряд Anseriformes - Гусеобразные}

5. Anas platyrhynchos Linnaeus, 1758 - кряква.

Обычный вид акватории водохранилища. Самка кряквы с выводком из 5 птенцов встречена 23.06.2018 на болотине рядом с водохранилищем. На Юрьинском пруду 25.06.2018 отмечена самка кряквы. Самка с выводком (не менее 7 птенцов) встречена 26.06.2018 у правого берега водохранилища недалеко от плотины. В 2019 г. в этих же местах отмечены выводки крякв из 4, 7 и 8 птенцов. Птенцы по размеру были немногим меньше взрослых птиц.
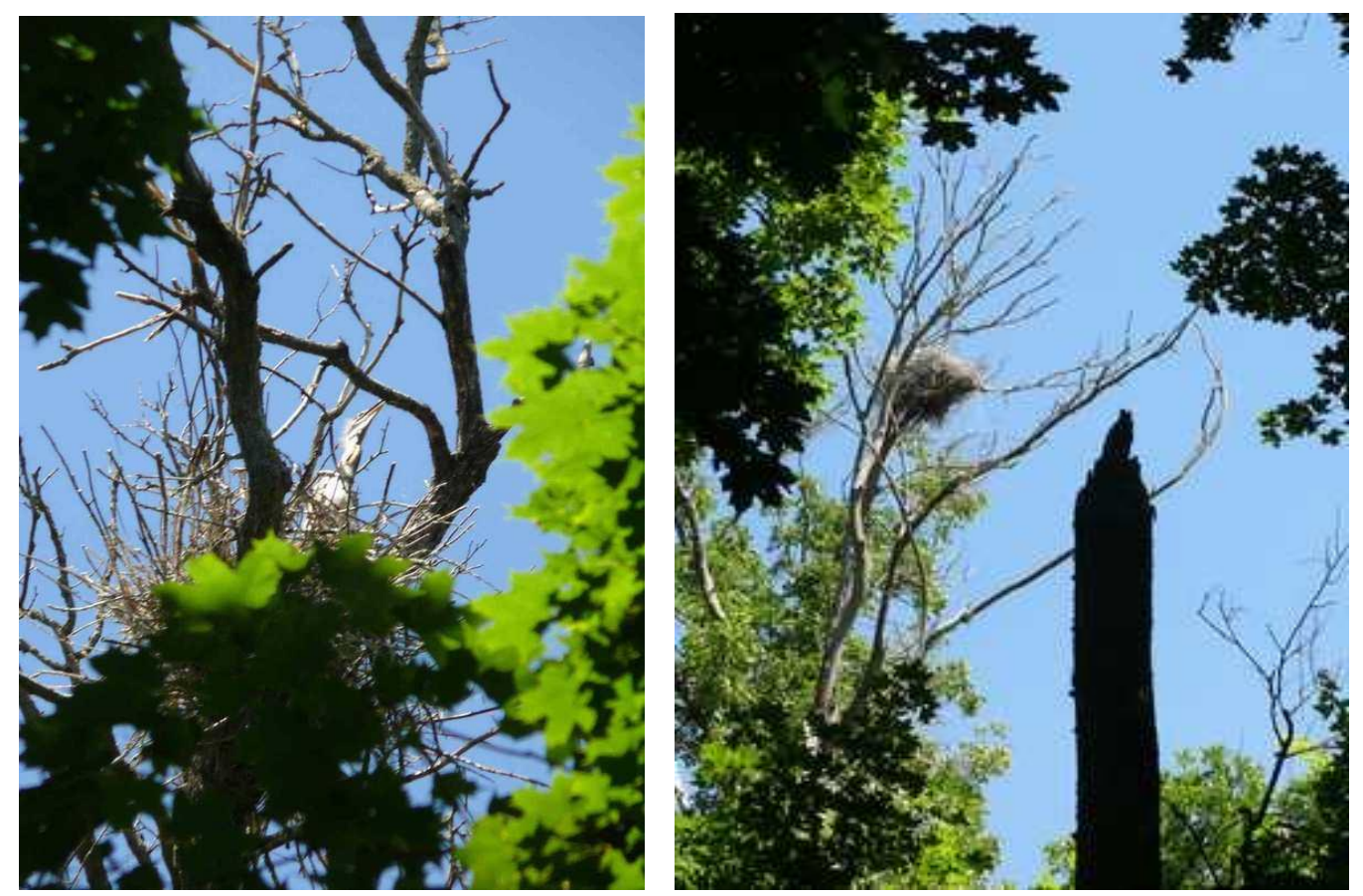

Рис. 5. Гнёзда серых цапель в лесополосе № 71, территория комплексного государственного природного заказника «Каменная степь» (фото А.Д. Нумерова)

Fig. 5. Nests of grey herons in forest belt № 71, territory of complex state nature reserve "Kamennaya Step" (photo by A. Numerov)

Отряд Falconiformes - Соколообразные

6. Milvus migrans (Boddaert, 1783) - чёрный коршун.

21.06.2018 и 24.06.2018 одиночную птицу наблюдали над степным участком недалеко от поселения сурков. Над водохранилищем (у полосы № 71) 22.06.2018 кружила одиночная птица, а 26.06.2018 отмечены три птицы над акваторией и одиночная особь - недалеко от плотины в низовьях водохранилища. Одиночная птица встречена у левого берега водохранилища 22.06.2019.

7. Buteo buteo (Linnaeus, 1758) - канюк.

Одиночная птица летала 22.06.2018 над вспаханным полем у полосы № 124; 23.06.2018 канюк встречен около плотины водохранилища; 26.06.2018 над полем, которое перепахивал трактор 4 особи летали. Два других канюка держались недалеко от колонии цапель в полосе № 71. Одиночная птица встречена у левого берега водохранилища 22.06.2019.

8. Hieraaetus pennatus (J.F. Gmelin, 1788) - орёл-карлик.

21.06.2019 особь светлой окрасочной морфы кружила над полем у лесополосы № 34.

9. Falco tinnunculus Linnaeus, 1758 - обыкновенная пустельга.

Как обычный гнездящийся вид, пустельга отмечалась с конца XIX в. [Силантьев, 1898]. Все последующие исследования подтверждали этот статус вплоть до конца ХХ в. 
[Огнев, Воробьёв, 1923; Марин, 1950; Семаго, 1960; Куликова, 1970; Турчин, 1991, 1999б]. Пустельга гнездилась в колониях грачей, которые располагались в высокоствольных лишённых подлеска полосах и гнёздах сорок [Огнев, Воробьёв, 1923; Турчин, 1996]. В 20182019 гг. колонии грача на территории Каменной степи отсутствовали, а сорока встречалась единично. Возможно, поэтому пустельгу мы встретили только два раза: 21.06.2018 одиночная птица кружила над степным участком недалеко от поселения сурков, 21.06.2019 одиночная птица встречена над скошенным участком луга около лесополосы № 40.

\section{Отряд Galliformes - Курообразные}

10. Coturnix coturnix (Linnaeus, 1758) - перепел.

В 2018 г. не отмечен. Во время осмотра территории в районе метеостанции 19.06.2019 взрослая птица вылетела из травы. Гнездо обнаружить не удалось. 24.06.2019 дважды крик перепела слышали на обочине скошенного участка луга возле полосы № 40.

\section{Fulica atra Linnaeus, 1758 - лысуха.}

\section{Отряд Gruiformes - Журавлеобразные}

Выводок из 7 птенцов отмечен 23.06.2018 на воде у зарослей левого берега водохранилища; 4 пары лысух с птенцами встречены 23.06.2019 недалеко от плотины.

\section{Отряд Charadriiformes - Ржанкообразные}

12. Chlidonias leucopterus (Temminck, 1815) - белокрылая крачка.

При обследовании водохранилища 26.06.2018 обнаружена небольшая колония из 10-12 пар. Осмотрено 9 гнёзд, из них в двух гнездах найдено по 1 яйцу, в двух гнездах по 2 яйца, в пяти гнёздах - по 3 яйца (рис. 6). Средняя кладка - 2,33 яйца на гнездо, средние размеры яиц 34,4 мм $\times 24,6$ мм $(\mathrm{n}=11)$. В 2019 г. из-за изменения обилия и структуры зарослей водных растений колония исчезла. Крачки не отмечены в 2019 г. и в других частях акватории водохранилища.
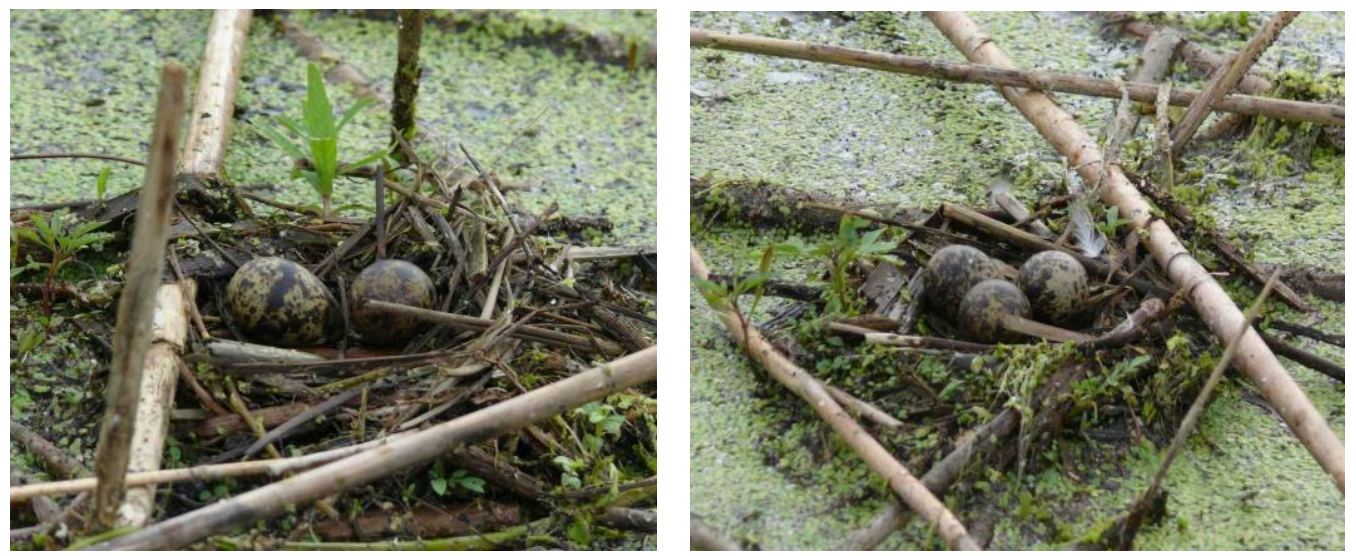

Рис. 6. Кладки белокрылой крачки с 2 и 3 яйцами на водохранилище, территория комплексного государственного природного заказника «Каменная степь», 26.06.2018 (фото А.Д. Нумерова)

Fig. 6. Clutches of white-winged tern with 2 and 3 eggs in the reservoir, territory of complex state nature reserve "Kamennaya Step"', 26.06.2018 (photo by A. Numerov)

13. Chlidonias hybridus (Pallas, 1811) - белощёкая крачка.

При обследовании водохранилища 26.06.2018 отмечены 3-4 пары белощёких крачек, которые держались рядом с колонией белокрылых. В 2019 г. белощёкая крачка в акватории водохранилища не отмечена. 


\section{Отряд Columbiformes - Голубеобразные}

14. Columba palumbus Linnaeus, 1758 - вяхирь.

Во время осмотра лесополосы № 138 обнаружены перо и останки 3 слётков, съеденных наземным хищником (вероятно, куницей). В 2019 г. в лесополосе № 40 обнаружены перья вяхиря, съеденного пернатым хищником.

15. Columba oenas Linnaeus, 1758 - клинтух.

Над территорией посёлка института 21.06 .2018 в 8.00 за 10 минут наблюдений на северо-запад пролетели 12 клинтухов по 2-3 особи. В 2019 г. также наблюдали пролетающих особей в северо-западном направлении. 23.06.2018 наблюдали 6 летящих особей, затем - 13, затем - 5, затем - 21 особь.

16. Columba livia J.F. Gmelin, 1789 - сизый голубь.

Отмечен с 21.06.2018 по 26.06.2018 одиночными птицами и небольшими группами в посёлке института и ближайших окрестностях. В 2019 г. пара чисто сизых (по окраске) голубей гнездилась в разрушенной котельной.

17. Streptopelia decaocto (Frivaldszky, 1838) - кольчатая горлица.

Обычный вид. 21.06.2018 слышали характерные крики в посёлке института. 22.06.2018 слышали крики не менее 3 пар в центре посёлка института. 23.06.2018 отмечена пара на окраине посёлка по дороге к водохранилищу. Наблюдали спаривание. В 2019 г. крики одиночных горлиц и пар регистрировали ежедневно весь период наблюдений.

18. Streptopelia turtur (Linnaeus, 1758) - обыкновенная горлица.

В XX в. на территории Каменной степи обыкновенная горлица отмечалась всеми исследователями как обычный многочисленный вид [Огнев, Воробьёв, 1923; Марин, 1950; Семаго, 1960; Куликова, 1970; Тунякина, 1998; Турчин, 2000]. Гнездилась в старых, широких и непродуваемых лесных полосах. Во время нашего пребывания птиц не встречали, но на окраине полосы № 34 было обнаружено старое гнездо, сходное по конструкции с гнездом обыкновенных горлиц. Во время учетов в 2011 г. в старовозрастных лесополосах не отмечена [Венгеров, Рубан, 2011]. В целом по Воронежской области в последнее десятилетие численность вида сократилась в 3-4 раза, а распространение приобрело мозаичный характер [Венгеров и др., 2019].

\section{Отряд Cuculiformes - Кукушкообразные}

19. Cuculus canorus Linnaeus, 1758 - обыкновенная кукушка.

26.06.2018 дважды слышали крик самки кукушки (напротив полосы № 71, правый берег водохранилища). В 2019 г. голоса 1-2 самцов слышали ежедневно в посёлке института и возле водохранилища.

\section{Отряд Strigiformes - Совообразные}

20. Asio otus (Linnaeus, 1758) - ушастая сова.

В июне 2018 г. по ночам в посёлке института постоянно были слышны крики кочующих после вылета из гнезда птенцов (не менее 2). В 2019 г. крики птенцов-слётков отмечены в парке института. В лесополосах не отмечена, возможно, из-за отсутствия старых гнездовых построек сорок и грачей.

21. Strix aluco Linnaeus, 1758 - серая неясыть.

По данным В.Г. Турчина [2000], в Каменной степи серая неясыть обитает только в старовозрастных лесополосах, имеющих ширину 30 и более метров. В связи с недостатком крупных дупел вынуждена селиться в многолетних гнёздах грачей и на чердаках зданий, примыкающих к лесополосам. Места обитания постоянны, численность стабильная 0,3 пары/100 га лесополос [Турчин, 2000]. Нами отмечена один раз в 2019 г., когда взрослая особь пролетала участок открытого пространства между лесополосами № 127 и 40. 


\section{Отряд Apodiformes - Стрижеобразные}

22. Apus apus (Linnaeus, 1758) - чёрный стриж.

Обычный вид. В течение всего времени пребывания регистрировали кружащих над посёлком птиц в количестве 25-40 особей. Ночной подъём птиц 21.06.2018 начался в 21:00. В 21:15 в небе наблюдали единичных особей. Начало подъёма птиц с 19.06.2019 по 21.06.2019 отмечено в 21:00, в 21:10 видны единичные птицы, 21:15 слышны слабые крики, но птиц уже не видно. Гнёзда стрижей в посёлке расположены под карнизами окон 2-этажных зданий.

Отряд Coraciiformes - Ракшеобразные

23. Alcedo atthis (Linnaeus, 1758) - обыкновенный зимородок.

В невысоком обрыве водохранилища 26.06.2018 найдена жилая нора с птенцами. Взрослые птицы кормили птенцов. В 2019 г. голос пролетающего зимородка слышали возле плотины 22 и 23 июня в срединной части акватории водохранилища.

24. Merops apiaster Linnaeus, 1758 - золотистая щурка.

Одиночная птица встречена над водохранилищем 22.06.2018.

\section{Отряд Upupiformes - Удодообразные}

25. Uрира ерорs Linnaeus, 1758 - удод.

Две особи встречены в 2018 г. в районе н.п. Гуляй поле. 23.06.2019 три особи отмечены в районе кладбища посёлка института.

\section{Отряд Piciformes - Дятлообразные}

26. Dryocopus martius (Linnaeus, 1758) - желна.

23.06.2018 в лесополосе № 40 в полусухом дубе на высоте 11 м найдено дупло желны, вероятно, старое. Другое старое дупло характерной формы обнаружено в лесополосе № 127.

27. Dendrocopos major (Linnaeus, 1758) - большой пёстрый дятел.

21.06.2018 г. в лесополосе № 156 обнаружено дупло с птенцами. Оно располагалось в клёне на высоте 8 м; 23.06.2018 в лесополосе № 40 обнаружено дупло дятла в дубе на высоте 5,5 м. Здесь же, в 120 м, найдено ещё одно дупло в дубе на высоте 4,5 м.

28. Dendrocopos syriacus (Hemprich et Ehrenberg, 1833) - сирийский дятел.

23.06.2018 г. в окрестностях посёлка и в лесополосе № 34 встречены самец и самка сирийского дятла; 24.06. 2018 и 25.06.2018 у Железняковского пруда встречена самка.

29. Dendrocopos minor (Linnaeus, 1758) - малый пёстрый дятел.

В лесополосе № 40 в клёне на высоте 4,5 м обнаружено дупло дятла. Другое дупло найдено в лесополосе № 33 в вязе на высоте 3,3 м от земли; 25.06.2018 в лесополосе № 127 взрослый самец долбил дерево; 19.06.2019 дятел встречен в насаждениях у северной границы посёлка института; 24.06.2018 дупло с птенцами обнаружено в иве на высоте 4,5 м недалеко от полосы № 114 .

\section{Отряд Passeriformes - Воробьеобразные}

30. Hirundo rustica Linnaeus, 1758 - деревенская ласточка.

22.06.2018 пять жилых гнёзд ласточек обнаружены под потолком первого этажа и два гнезда - на втором этаже в полуразрушенном здании дизельной станции в посёлке института. Две пары отмечены 23.06.2018 по дороге из посёлка к плотине. В 2019 г. летающих ласточек наблюдали ежедневно в посёлке института. Не менее 3 пар гнездится в гаражах, а также в пустующем трёхэтажном здании с выбитыми стеклами верхнего этажа (4-5 птиц постоянно залетали внутрь).

31. Delichon urbica (Linnaeus, 1758) - воронок.

Обычный вид. В 1990-х годах в посёлке на здании института гнездилось 4-5 пар [Турчин, 2000]. Наше специальное обследование многоэтажных зданий показало, что в посёлке института на 6 зданиях расположены 60 жилых гнёзд ласточек. Кроме того, на этих же домах находилось еще 50 остатков разрушенных гнёзд. Более 70 \% жилых гнёзд располагались под карнизами зданий с северной и восточной сторон. 
32. Alauda arvensis Linnaeus, 1758 - полевой жаворонок.

На поле, рядом с некосимой залежью недалеко от метеостанции 25.06.2018 встречены два поющих самца.

33. Anthus trivialis (Linnaeus, 1758) - лесной конёк.

На границе лесополосы № 40 и скошенного участка с ЛЭП токовал самец лесного конька. Два других токующих самца в 2018 г. отмечены в лесополосе № 33; 19.06.2019 токующий самец встречен у северной границы посёлка института; 21.06.2019 во время обследования лесополосы № 40 слышали песню одного самца.

34. Motacilla flava Linnaeus, 1758 - жёлтая трясогузка.

Одиночная особь встречена на левом берегу водохранилища у плотины 26.06.2018.

35. Motacilla alba Linnaeus, 1758 - белая трясогузка.

Возле лесной полосы № 156 встречен хорошо летающий слёток 21.06.2018. У плотины водохранилища 23.06.2018 встречена пара трясогузок. В 2019 г. две встречи взрослых птиц отмечены 23.06.2018 и 24.06.2018 на окраине посёлка у гаражей.

36. Lanius collurio Linnaeus, 1758 - обыкновенный жулан.

На некосимом участке луга у метеостанции 24.06.2018 встречен выводок из 3 слетков, которых кормили взрослые птицы. Самец и самка встречены в прибрежном кустарнике в низовьях водохранилища 25.06.2018 и 26.06.2018. В 2019 г. самец встречен 23 июня у плотины водохранилища.

37. Oriolus oriolus (Linnaeus, 1758) - обыкновенная иволга.

21.06.2018 в лесополосе № 156 слышали песню иволги; 22.06.2018 поющий самец отмечен в лесополосе № 155, а 26.06.2018 - недалеко от плотины в низовьях водохранилища. В 2019 г. песню иволги слышали 21 июня у южной окраины посёлка, 21 и 22 июня в парке посёлка, лесополосах по левому берегу водохранилища. В районе плотины водохранилища 22.06.2019 встречена взрослая птица с кормом в клюве. Другая птица встречена 24 июня возле лесополосы № 127.

38. Sturnus vulgaris Linnaeus, 1758 - обыкновенный скворец.

На берегу водохранилища (у лесополосы № 71) 22.06.2018 в иве найдено дупло с птенцами. Взрослая птица с кормом находилась рядом. Двух кормящихся птиц наблюдали также 22.06.2019 у Железняковского пруда.

39. Garrulus glandarius (Linnaeus, 1758) - сойка.

В середине некосимой залежи, заросшей кустарником и подростом деревьев, 25.06.2018 г. рядом с лесной полосой № 138 на клёне на высоте 3 м обнаружено гнездо с 4 птенцами в возрасте 15-18 дней (рис. 7). При осмотре на птенцах обнаружены имаго кровососущих мух (сем. Hippoboscidae). Птенцы окольцованы. В 2019 г. одиночная птица встречена в посёлке института 22 и 24 июня, и 24 июня в лесополосе № 127 слышали характерный крик сойки.

40. Pica pica (Linnaeus, 1758) - сорока.

Одиночная птица встречена в насаждениях на берегу водохранилища в районе н.П. Гуляй поле. Отмечен 23.06.2018 выводок в зарослях кустарника на левом берегу водохранилища; 22.06.2019 выводок (не менее 3 молодых) в сопровождении взрослых птиц встречен приблизительно в том же месте, что и в предыдущем году.

41. Corvus frugilegus Linnaeus, 1758 - грач.

Колоний, которые существовали ранее на территории Каменной степи [Турчин, 2000], в настоящее время нет. Две птицы встречены в 2018 г. у дороги около н.п. Гуляй поле.

42. Corvus (corone) cornix Linnaeus, 1758 - серая ворона.

Выводок отмечен в районе кладбища 23.06.2018. Четыре особи (возможно выводок) встречены у водохранилища в районе н.п. Гуляй поле.

43. Corvus corax Linnaeus, 1758 - ворон.

Одиночную птицу наблюдали 22.06.2018 в лесополосе № 71. Характерные звуки слышали 25.06.2018 во время обследования лесополосы № 34. В лесополосе № 33 обнаружены останки ворона, съеденного хищником. 


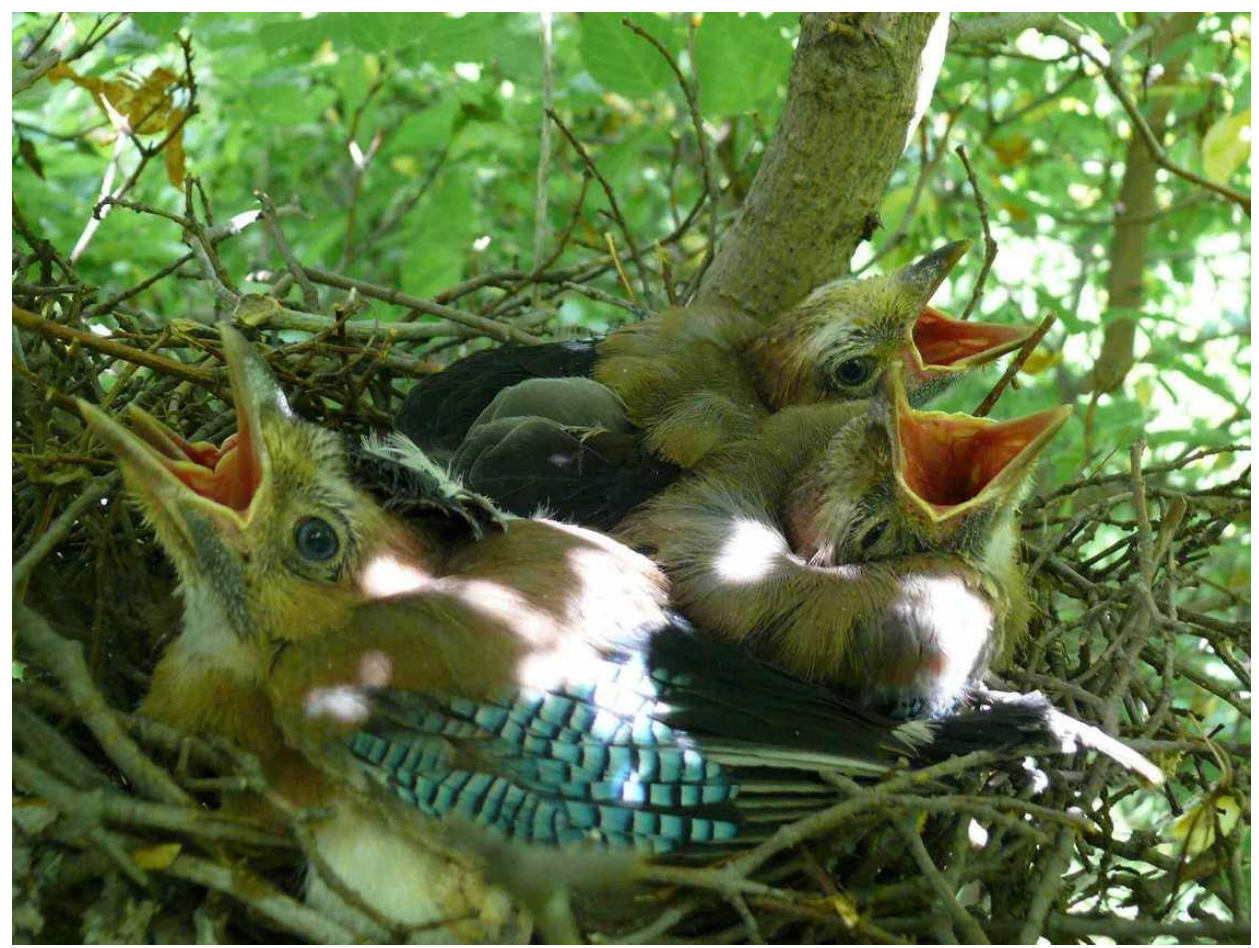

Рис. 7. Птенцы сойки в гнезде, территория комплексного государственного природного заказника «Каменная степь», 25.06 .2018 (фото А.Д. Нумерова)

Fig. 7. Jay chicks in the nest, territory of complex state nature reserve "Kamennaya Step", 25.06.2018 (photo by A. Numerov)

44. Acrocephalus arundinaceus (Linnaeus, 1758) - дроздовидная камышёвка.

На берегу водохранилища в районе лесополосы № 71 с одной точки слышна песня 3 самцов. Одиночный самец отмечен 26.06.2018 у водохранилища в районе н.п. Гуляй поле. В 2019 г. в небольших заводях по левому берегу через каждые 300-400 м наблюдался поющий самец.

45. Hippolais icterina (Vieillot, 1817) - зелёная пересмешка.

В 2019 г. одиночную поющую взрослую птицу слышали и наблюдали 21 июня в парке института.

46. Sylvia atricapilla (Linnaeus, 1758) - славка-черноголовка.

Поющего самца наблюдали 25.06.2018 недалеко от парка посёлка института.

47. Sylvia borin (Boddaert, 1783) - садовая славка.

Встречена 24.06.2018 в лесополосе № 138 .

48. Sylvia communis Latham, 1787 - серая славка.

21.06.2018 в лесной полосе № 156 пойман плохо летающий птенец-слёток, на котором находилось 3 мухи-кровососки (сем. Hippoboscidae); 24.06.2018 в лесополосе № 127 отмечены 2 особи и старое гнездо в кусте бузины; 24.06.2019 одиночную славку встретили возле полосы № 127.

49. Phylloscopus collybita (Vieillot, 1817) - пеночка-теньковка.

22.06.2018 в лесополосе № 71 токовал самец. В парке посёлка института 25.06.2018 встречен токующий самец, другая птица отмечена около Юрьинского пруда. В 2019 г. токующие самцы встречены в лесополосах у левого берега водохранилища 22 и 24 июня.

50. Ficedula hypoleuca (Pallas, 1764) - мухоловка-пеструшка.

Самец отмечен 25.06.2018 в лесополосе № 33.

51. Ficedula albicollis (Temminck, 1815) - мухоловка-белошейка.

Самец встречен 24.06.2019 в лесополосе № 40.

Отметим, что во время посещения старовозрастных лесополос и в 2018, и в 2019 гг. мы неоднократно наблюдали хорошо летающих слётков мухоловок (пеструшки или белошейки), но определить их видовую принадлежность без отлова не представлялось возможным. 
52. Ficedula (parva) parva (Bechstein, 1794) - малая мухоловка.

Единственная встреча поющего самца отмечена 23.06.2018 в лесополосе № 40.

53. Muscicapa striata (Pallas, 1764) - серая мухоловка.

25.06.2018 во время обследования лесополосы № 34 встречен плохо летающий выводок (3-4 слетка). На одном из пойманных птенцов обнаружена муха-кровососка. Другой выводок встречен в конце полосы. Ещё один выводок встречен в парке посёлка института. В лесополосе № 33 на обломке вяза на высоте 3 м найдено разорённое гнездо мухоловки с остатками скорлупы.

В 2019 г. в лесополосе № 160 на обломке клёна на высоте 3,5 м найдено гнездо. Судя по характерным признакам, выводок вылетел. Взрослые кормящиеся особи встречены с 21 по 24 июня в лесополосе № 40 (3 особи), в парке института (2 особи), во время экскурсии к плотине водохранилища (5 особей) и одна птица замечена на проводах ЛЭП у лесополосы № 127.

54. Saxicola rubetra (Linnaeus, 1758) - луговой чекан.

На 4-километровом маршруте по северной окраине посёлка института 19.06.2019 встречены 2 самки с выводками. Одиночный самец отмечен у левого берега водохранилища 22.06.2019.

55. Phoenicurus phoenicurus (Linnaeus, 1758) - обыкновенная горихвостка.

Самец и самка горихвостки с выводком плохо летающих слетков встречены 21.06.2019 в парке института. Птицы постоянно издавали тревожные крики.

56. Phoenicurus ochruros (S.G. Gmelin, 1774) - горихвостка-чернушка.

Обычный многочисленный вид. Встречена 21, 23 и 25 июня 2018 г. в различных местах посёлка института. В 2019 г. Слышали пение или наблюдали самих птиц ежедневно. Массовый вид в посёлке института.

57. Erithacus rubecula (Linnaeus, 1758) - зарянка.

В 2018 г. в лесополосе № 33 в вязе на высоте 1,3 м от земли в полудупле найдено гнездо с 6 яйцами (рис. 8), находящееся на расстоянии 7 м до края лесополосы. Птица насиживала яйца.
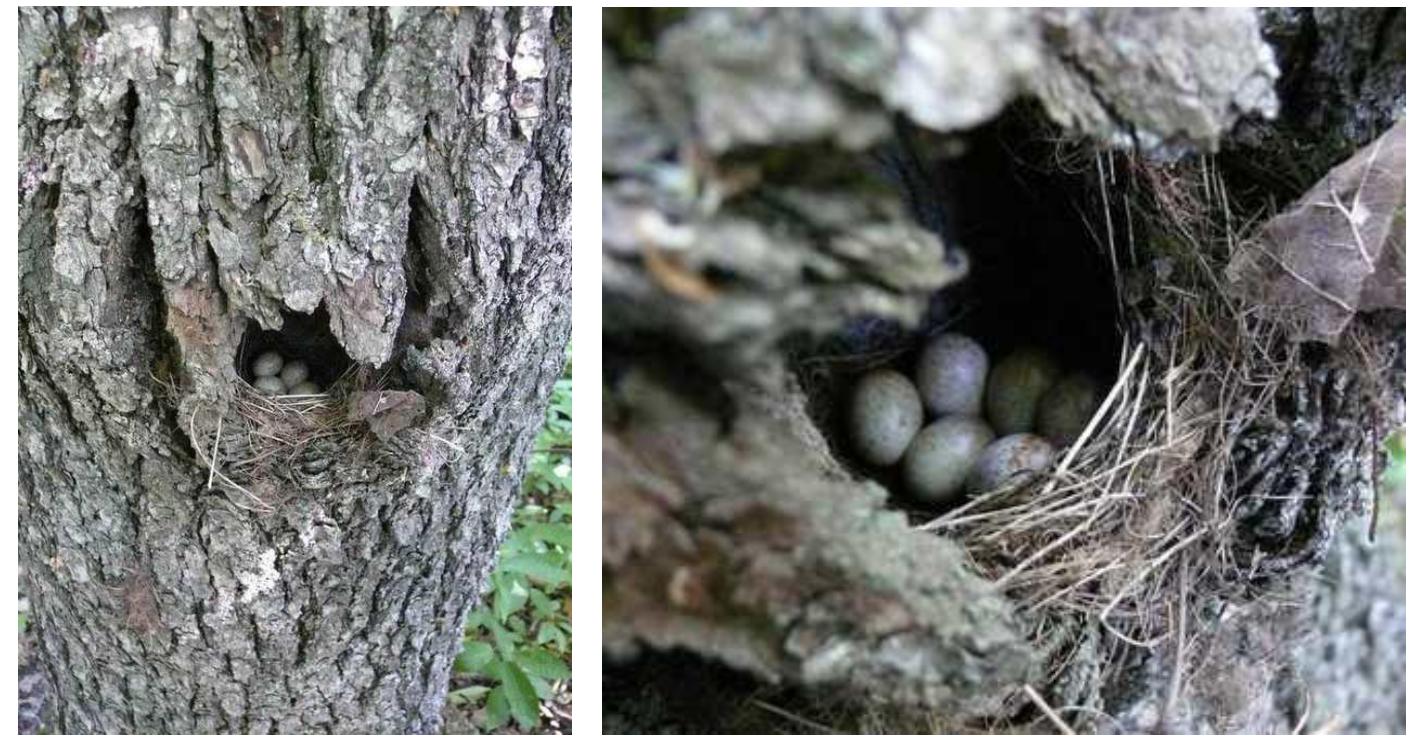

Рис. 8. Гнездо зарянки в полудупле вяза, территория комплексного государственного природного заказника «Каменная степь», 2018 г. (фото А.Д. Нумерова)

Fig. 8. A nest of a robin in an elm half-trunk, territory of complex state nature reserve "Kamennaya Step'", 2018 (photo by A. Numerov)

В 2019 г. взрослую птицу и выводок молодых наблюдали 21 июня в парке института. Птицы разыскивали корм на земле. 
58. Luscinia luscinia (Linnaeus, 1758) - обыкновенный соловей.

Пару взрослых беспокоящихся птиц (вероятно, рядом находился выводок) наблюдали 24.06.2019 в зарослях кустарника возле полосы № 40. Тревожные позывки другой пары слышали на южной окраине парка института.

59. Luscinia svecica (Linnaeus, 1758) - варакушка.

Недалеко от плотины водохранилища 23.06.2018 встречен белозвёздный самец. Самец пел 25.06.2018 в кустарнике на берегу Железняковского пруда. В 2019 г. токующие самцы встречены 22 и 23 июня в зарослях кустарника левого берега водохранилища.

60. Turdus pilaris Linnaeus, 1758 - рябинник.

Одна птица попала в давилку 22.06.2019 в полосе № 40. Взрослого беспокоящегося дрозда встретили 24.06.2019 возле полосы № 127.

61. Turdus merula Linnaeus, 1758 - чёрный дрозд.

21.06.2018 слышали песню, но вполголоса. Одиночную птицу наблюдали 22.06.2018 в лесополосе № 71; 23.06.2018 во время обследования лесополосы № 40 зарегистрировали 2 поющих самцов. Найдено пустое гнездо (выводок был) на клёне американском, высота 2,5 м; 24.06.2018 встречен в лесополосе № 127; 25.06.2018 в лесополосе № 33 на вязе найдено старое гнездо.

19.06.2019 слышали голос дрозда (песня не полная), 21.06.2019 в парке института встречен взрослый самец, выводок (не менее 5 молодых) отмечен 22.06.2019 возле Железняковского пруда; 24.06.2019 в лесополосе № 127 наблюдали взрослую птицу с кормом в клюве, а плохо летающего слётка - в парке института.

62. Turdus philomelos C.L. Brehm, 1831 - певчий дрозд.

23.06.2018 в лесополосе № 40 на дубе на высоте 7 м найдено гнездо с 4 птенцами в возрасте 3-4 дней, другое свежее пустое гнездо обнаружено на груше на высоте 2,2 м. В лесополосе № 127 найдена половинка скорлупы яйца после вылупления. В лесополосе № 138 обнаружено 24.06.2018 старое гнездо и скорлупа съеденной кладки певчего дрозда, а в насаждениях близ метеостанции встречен слёток. 25.06.2018 в полосе № 34 г. обнаружено 2 гнезда на дубах (высота 5,5 и 6,5 м), в полосе № 33 - два гнезда на вязах на высоте 2 и 5 м. В этот же день две птицы встречены около Железняковского и Юрьинского прудов.

21.06.2019 при обследовании лесополос № 40, 34 и 127 обнаружено только одно пустое гнездо, а в каждой из полос встречено по одной особи. Выводок молодых наблюдали 21.06.2019 в парке института. Птицы разыскивали корм на земле. По одной взрослой птице отмечено 22 и 23 июня во время экскурсий недалеко от левого берега водохранилища. Плохо летающий слёток встречен 24.06.2019 возле лесополосы № 127.

63. Remiz pendulinus (Linnaeus, 1758) - обыкновенный ремез.

При обследовании водохранилища 26.06.2018 в прибрежных зарослях на иве обнаружены два свежих гнезда и одно недостроенное (рис. 9). Птиц рядом не было.

64. Parus caeruleus Linnaeus, 1758 - лазоревка.

Выводок лазоревок из 8-10 слетков встречен 21.06.2018 возле водохранилища в районе лесополосы № 71; 23.06.2018 в лесополосе № 40 в дупле клёна на высоте 2,5 м обнаружен выводок лазоревки. Рядом - взрослая птица с кормом. В 300 м другая пара кормила слетков. В 2019 г. выводок лазоревок (не менее 6 слетков) встречен 22 июня возле сильно пересохшего Железняковского пруда.

65. Parus major Linnaeus, 1758 - большая синица.

Встречена 22.06.2018 у маленького пруда, 23.06.2018 - в лесополосе № 40 одна особь и в конце полосы - выводок, 25.06.2018 в лесополосе № 33 - взрослая особь и выводок, две особи в лесополосе № 34. Во время обследования лесополосы № 40 зарегистрировано 6 особей 21.06.2019. 

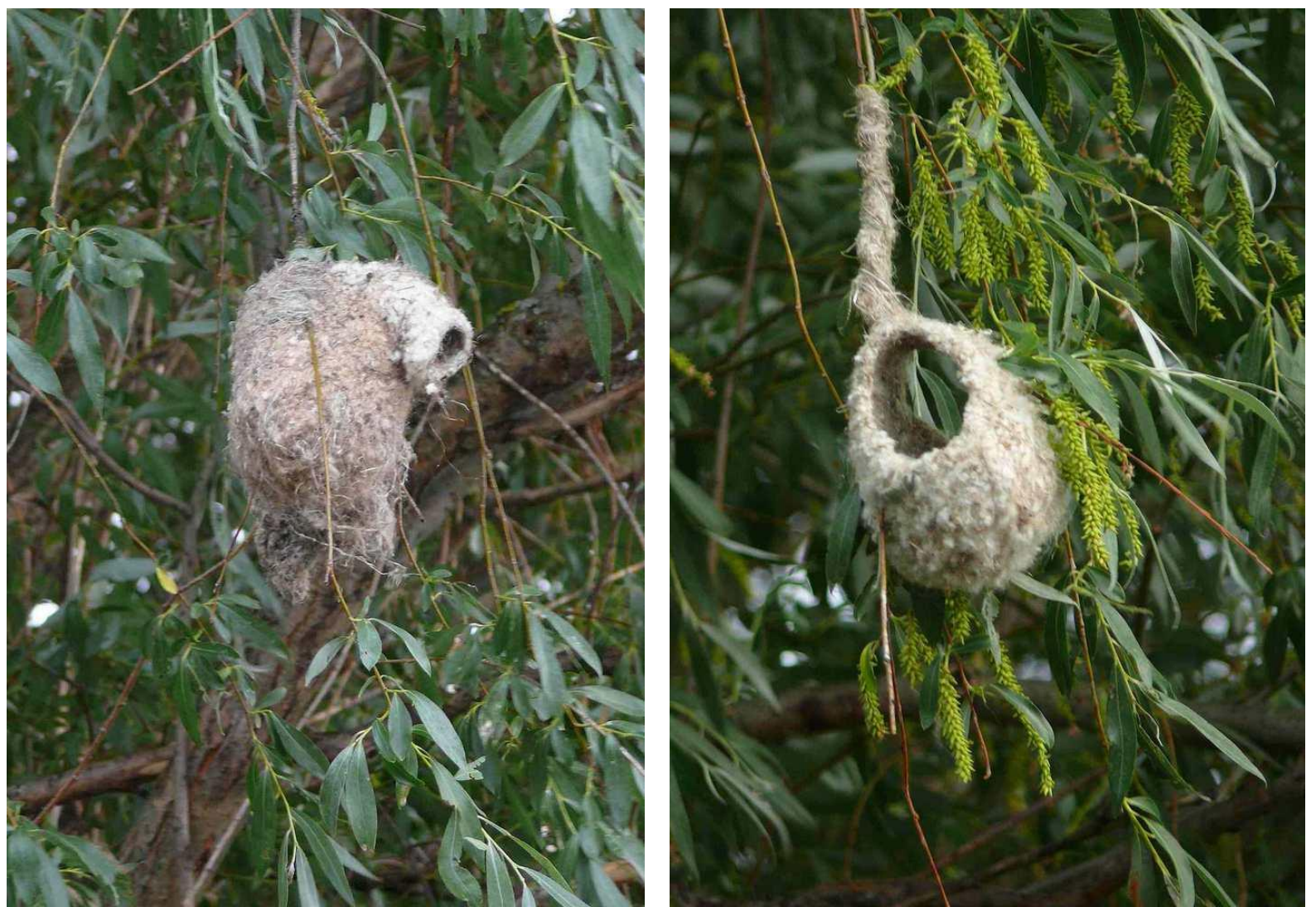

Рис. 9. Готовое и недостроенное гнёзда ремеза на берегу водохранилища, территория комплексного государственного природного заказника «Каменная степь», 2018 г. (фото А.Д. Нумерова)

Fig. 9. Finished and unfinished nests of penduline tit on the bank of the reservoir, territory of complex state nature reserve "Kamennaya Step", 2018 (photo by A. Numerov)

66. Sitta europaea Linnaeus, 1758 - обыкновенный поползень.

22.06.2018 в посёлке института и полосе № 156 слышали характерные крики. Крики и сами птицы зарегистрированы также в лесополосах № 40, 127, 34. В 2019 г. характерные позывки поползня слышали ежедневно в парке посёлка института и в полосах № 40, 127, 34 и лесополосах по левому берегу водохранилища.

67. Passer montanus (Linnaeus, 1758) - полевой воробей.

Обычный многочисленный вид. Гнёзда отмечены под карнизами окон 2-этажных зданий. 22.06.2018 взрослые птицы летали с кормом для птенцов. 21.06.2019 в парке института небольшие группы по 4-5 особей собирали корм на земле. 23.06.2019 во время экскурсии по посёлку к водохранилищу (примерно 2 км) учтено 25 особей.

Интересно отметить, что за всё время наблюдений нами не был встречен домовый воробей. Хотя в 1894-1896 гг. на данной территории, до массовой посадки лесополос, наряду с полевым отмечался и домовый воробей [Силантьев, 1898]. Отсутствовал домовый воробей и в списках гнездящихся птиц по данным наблюдений в XX в. [Огнев, Воробьёв, 1923; Кистяковский, 1936; Марин, 1950; Семаго, 1960; Куликова, 1970; Тунякина, 1998].

68. Fringilla coelebs Linnaeus, 1758 - зяблик.

Многочисленный вид. Встречен по всей территории. 22.06.2018 в лесополосе № 40 с одного места одновременно были слышны голоса 3 самцов. 25.06.2018 рядом с тропинкой, пересекающей полосу № 40, на вязе на высоте 3,5 м обнаружено пустое гнездо. 24.06.2018 в лесополосе № 138 встречены два поющих самца и два гнезда на клёне (высота -6 м) и разорённое на земле. Во время обследования 25.06.2018 в полосе № 34 учтено 9 поющих самцов. Пустое гнездо (после вылета птенцов) обнаружено на клёне на высоте 
2,7 м; 25.06.2018 в полосе № 33 учтено 6 поющих самцов и гнездо на клёне на высоте 2,2 м. Другое гнездо обнаружено на клёне недалеко от Юрьинского пруда на высоте 5,5 м.

21.06.2019 во время обследования лесополосы № 40 зарегистрировано 5 поющих самцов, в полосе № 127 - 6 самцов и выводок, в лесополосе № $34-7$ поющих самцов. В парке института в 16:00 с одного места были слышны голоса 4 поющих самцов.

69. Chloris chloris (Linnaeus, 1758) - обыкновенная зеленушка.

Поющих птиц отмечали в посёлке ежедневно с 21 по 26 июня 2018 г.; 23.06.2018 в лесополосе № 40 найдено гнездо зеленушки (клён американский, высота - 5 м). Рядом поёт самец. Одиночная птица встречена в насаждениях на правом берегу водохранилища напротив лесополосы № 71. Поющие самцы отмечены 23.06.2018 и 25.06.2018 в насаждениях у плотины и Железняковского пруда. Во время обследования 21.06.2019 лесополосы № 40 зарегистрировано 2 поющих самца.

70. Spinus spinus (Linnaeus, 1758) - чиж.

Характерные позывки нескольких чижей слышали в парке института 21.06.2019 и 24.06.2019 в лесополосе № 127.

71. Carduelis carduelis (Linnaeus, 1758) - щегол.

Встречен 21.06.2018 и 25.06.2018 в полосе № 34; 22.06.2018 - в посёлке института; 25.06.2018 самец пел у Железняковского пруда. В 2019 г. голос поющих самцов и встречи пролетающих птиц регистрировали почти ежедневно.

72. Acanthis cannabina (Linnaeus, 1758) - коноплянка.

В посёлке института 21.06.2018 на проводах встречен самец. Поющий самец встречен 24.06.2019 в посёлке института.

73. Carpodacus erythrinus (Pallas, 1770) - обыкновенная чечевица.

Песню слышали 22.06.2018 возле водохранилища в районе полосы № 71 .

74. Coccothraustes coccothraustes (Linnaeus, 1758) - обыкновенный дубонос.

Выводок встречен 22.06.2018 возле водохранилища в районе полосы № 71 . В 2019 г. выводок встречен 21 июня у южной окраины посёлка, а другой выводок - в парке института.

75. Emberiza citrinella Linnaeus, 1758 - обыкновенная овсянка.

Обычный вид. Поющий самец отмечен на дачном участке у посёлка института. Здесь же находилось гнездо с маленькими птенцами, но к моменту осмотра (22.06.2018) оно было разорено. 23.06.2018 в полосе № 40 пел самец, еще два отмечены 25.06.2018 в лесополосе № 34 и один - в полосе № 33. Поющий самец встречен в 2018 г. в насаждениях на правом берегу водохранилища напротив лесополосы № 71. 19.06.2019 два поющих самца отмечены у северной окраины посёлка института. Характерную песню овсянок слышали ежедневно (с 19 по 24 июня) во время экскурсий по территории и обследования лесополос.

76. Emberiza hortulana Linnaeus, 1758 - садовая овсянка.

Токующий самец встречен 19.06.2019 недалеко от поселения сурков.

Класс Mammalia - Млекопитающие

Отряд Eulipotyphla - Насекомоядные

1. Erinaceus roumanicus Barrett-Hamilton, 1900 - южный ёж.

Очевидно, как и везде по области, ёж обычен в Каменной Степи. На довольно частые его встречи здесь указывали еще в начале прошлого века С.И. Огнев и К.А. Воробьёв [1923]. Нами один взрослый ёж был встречен 23.06.2018 вечером в сумерках на обочине грунтовой дороги между старовозрастными лесополосами № 34 и 40.

2. Sorex (gr. «minutus») minutus Linnaeus, 1766 - малая бурозубка.

По-видимому, обычный немногочисленный вид лесополос Каменной Степи. Одно из первых упоминаний этого вида в литературе для Воронежской тогда еще губернии относится именно к Каменной Степи [Огнев, Воробьёв, 1923]. 
Нами была поймана одна взрослая малая бурозубка 24.06.2018 в давилку во время ночного учёта в лесополосе № 34. Общая относительная численность вида в лесополосах составила 0,5 экз. на 100 ловушко-ночей.

3. Sorex (gr. «araneus») araneus Linnaeus, 1758 - обыкновенная бурозубка.

Обычный, хотя и немногочисленный вид старых лесополос. В лесополосе № 34 была добыта одна взрослая обыкновенная бурозубка во время учёта мелких млекопитающих ловушко-линиями 25.06.2018. Общая относительная численность данного вида в старовозрастных лесополосах составила 0,5 экз. на 100 ловушко-ночей.

\section{Отряд Chiroptera - Рукокрылые}

4. Myotis daubentonii Kuhl, 1817 - водяная ночница.

По-видимому, редкий вид. Во время акустического мониторинга ультразвуковых сигналов летучих мышей нами был зафиксирован единственный случай обнаружения этой ночницы 20.06.2019 в 22 часа на скошенном разнотравном участке у старовозрастной лесополосы № 127.

5. Myotis dasycneme Boie, 1825 - прудовая ночница.

Редкий вид. Ультразвуковые сигналы прудовой ночницы были отмечены только один раз на территории посёлка 25.06.2019 около 2 часов ночи.

6. Plecotus auritus Linnaeus, 1758 - бурый, или обыкновенный, ушан.

Редкий вид. Звуковые сигналы ушана отмечены всего дважды на территории посёлка 25.06.2019 в 2 часа ночи с интервалом 15 минут. Возможно, они исходили от одного зверька.

7. Nyctalus noctula (Schreber, 1774) - рыжая вечерница.

Обычный вид. На его долю приходилось 7,3 \% звуковых сигналов летучих мышей, определённых до вида. Зверьки чаще встречались в посёлке и чуть реже - у лесополос. Всего было зафиксировано 14 сигналов рыжей вечерницы, из них в посёлке -9 .

8. Nyctalus leisleri (Kuhl, 1817) - малая вечерница.

Обычный, немногочисленный вид. Его звуковые сигналы (4 сигнала) были отмечены как в посёлке, так и вблизи лесных полос.

9. Nyctalus lasiopterus (Schreber, 1780) - гигантская вечерница.

Повсеместно редкий вид, внесённый в Красную книгу РФ и Красные книги некоторых областей России. В наших наблюдениях в условиях Каменной Степи 5 звуковых сигналов гигантской вечерницы были записаны в посёлке 25.06.2019 с 03:05 до 03:45 часов с интервалом 5-10 минут. Возможно, это были сигналы одного и того же зверька.

10. Pipistrellus nathusii Keiserling et Blasius, 1839 - лесной нетопырь, или нетопырь Натузиуса.

Самый многочисленный вид летучих мышей Каменной Степи. Были записаны 107 звуковых сигналов зверьков этого вида, что составило 56,6 \% от всех остальных видов. Этот нетопырь встречался повсеместно, хотя несколько чаще в посёлке, где было зафиксировано более половины сигналов (62 сигнала).

11. Pipistrellus (gr. «pipistrellus») pipistrellus (Schreber, 1774) - нетопырь-карлик.

Обычный, многочисленный вид. Зарегистрировано 24 звуковых сигнала этого нетопыря, что составило 12,7 \% от всех остальных видов рукокрылых. Он занимал второе место по частоте встречаемости после лесного нетопыря. Почти все зверьки были отмечены вблизи лесополос вне населённого пункта.

12. Pipistrellus (gr. «pipistrellus») pygmaeus (Leach, 1825) - малый, или тонкоголосый, нетопырь.

Редкий вид в условиях Каменной Степи. 22.06.2019 в 22:40 отмечен единственный случай обнаружения этого нетопыря на пешем маршруте по дороге от лесной полосы № 34 вдоль лесополос № 40 и 127 до края посёлка. морский.

13. Pipistrellus (gr. «kuhlii») kuhlii (Kuhl, 1817) - нетопырь Куля, или средиземно- 
До недавнего времени ареал этого вида располагался гораздо южнее и югозападнее Воронежской области. В 1930-1950 гг. началось продвижение этого нетопыря на север, особенно интенсивно в 1970-х гг. [Pipistrellus kuhli.., 2021]. В Воронежской области этого нетопыря впервые обнаружили в марте 2005 г. - зверёк во время оттепели залетел в окно одной из школ г. Павловска. В 2007 г. одиночного погибшего зверька нашли в главном корпусе Воронежского государственного университета. В последующие годы встречи этого вида были отмечены в Воронежском и Хоперском заповедниках и неоднократно в разные годы в г. Воронеже [Климов, Химин, 2018].

К настоящему времени накопилось уже много сведений о находках нетопыря Куля на территории Воронежского края. Обычен этот вид и в условиях Каменной Степи. Звуковые сигналы нетопырей Куля были 6 раз зарегистрированы здесь во время акустического мониторинга рукокрылых. Из них пять сигналов были записаны в посёлке и один на косимом участке у лесополосы № 127.

14. Vespertilio murinis Linnaeus, 1758 - двухцветный кожан.

Обычный, немногочисленный вид Каменной степи. Было зарегистрировано 5 звуковых сигналов этого вида (2,6 \% от всех остальных видов рукокрылых). Все зверьки были встречены вблизи лесных полос, главным образом на косимом участке у лесополосы № 127.

15. Eptesicus serotinus (Schreber, 1774) - поздний кожан.

До конца 70-х гг. XX в. поздний кожан был редким видом юга Воронежской области. Первые известные встречи этого вида в области (в 1935 г.) относятся именно к Каменной степи [Барабаш-Никифоров, 1957]. В последующие десятилетия началось расширение ареала и продвижение этого вида в северном и южном направлении [Eptesicus serotinus..., 2021]. В настоящее время поздний кожан стал уже довольно обычным видом Воронежской области. Обычен он и в Каменной степи, занимая по частоте встреч 3 место среди учтённых рукокрылых. Всего было записано 19 сигналов поздних кожанов, что составило $10,1 \%$ от остальных видов мышей. Большая часть их была отмечена на косимом участке у лесных полос № 40 и 127 (11 сигналов) и 3 сигнала в посёлке.

\section{Отряд Rodentia - Грызуны}

16. Marmota (gr. «bobak») bobak (Müller, 1776) - сурок-байбак.

Некогда многочисленный типичный вид степной фауны Воронежского края в настоящее время в условиях Каменной Степи находится на грани исчезновения. Ещё в середине XIX в., когда общий ареал сурка значительно сократился, Н.А. Северцов отмечал этот вид как довольно многочисленный в Каменной Степи и в степи по верхнему течению p. Икорца [Северцов, 1950]. Однако в последующие десятилетия население зверька заметно сократилось. В 1898 г. А.А. Силантьев писал: «В Бобровском уезде, на Каменной Степи, существует еще сурочий промысел, значительно упавший за последние годы...» [Силантьев, 1898, с. 16]. Возможно, помимо повсеместной распашки степных участков, именно перепромысел байбаков привел к их почти полному исчезновению с территории Воронежской области.

Вероятно, единственная колония этих зверьков сохранилась до середины прошлого века именно в Каменной Степи. Так, С.И. Огнев отмечал, что в начале века (19191922 гг.) в Каменной Степи держалось большое количество сурков, особенно на твёрдых залежах, в частности на целине [Огнев, 1947]. К середине века число зверьков резко сократилось. Поселения зверьков располагались здесь в двух местах на заповедных косимых залежных участках, первое - севернее, а второе - южнее посёлка 2-го участка института им. В.В. Докучаева (рис. 10). 


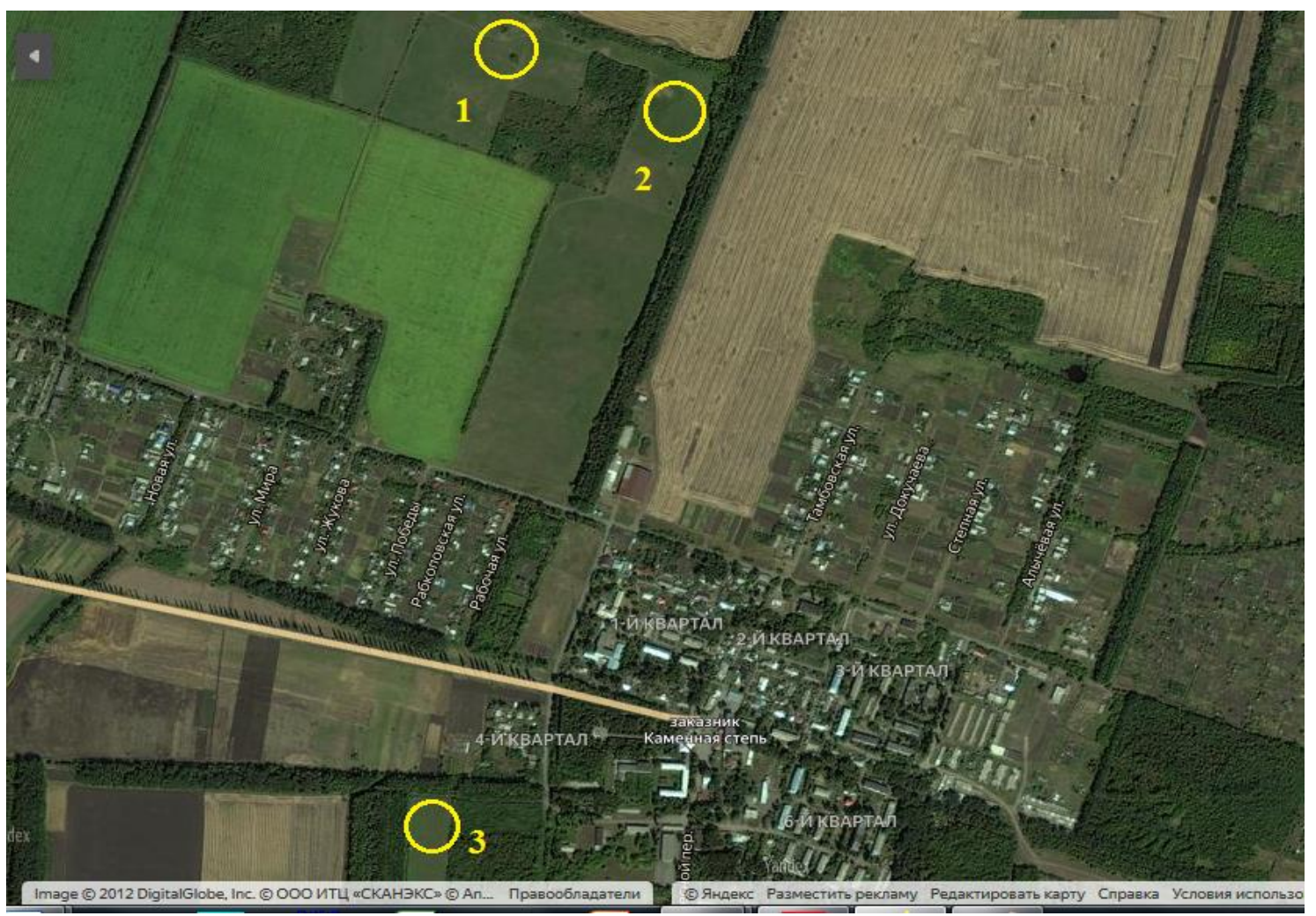

Рис. 10. Расположение поселений сурка-байбака на территории комплексного государственного природного заказника «Каменная степь», окрестности посёлка 2-го участка

Научно-исследовательского института сельского хозяйства имени В.В. Докучаева: 1 - поселения 1946-2019 гг.; 2, 3 - 1950-е гг.

Fig. 10. The location of settlements of bobak marmot in territory of complex state nature reserve

"Kamennaya Step'", vicinity of village of $2^{\text {nd }}$ section of Scientific Research Institute of Agriculture named after V.V. Dokuchaev (1 - settlements 1946-2019; 2, 3 - 1950s)

В 1946-1947 гг. в обоих поселениях насчитывалось около 1000 сурков, к 1951 г. их численность сократилась до 520 шт., а к 1956 г. их осталось не более 300 шт. Резкое сокращение численности произошло из-за полного выкашивания залежных участков, на которых жили байбаки, а также в результате масштабной распашки соседних участков, которые хотя и меньше, но тоже использовались зверьками [Александров, 1951; БарабашНикифоров, Александров, 1953; Барабаш-Никифоров, 1957].

В настоящее время из указанных поселений сохранилось только первое. Оно размещено на косимой залежи на участке площадью около 8 га и располагается в 500 м севернее метеорологической станции посёлка (рис. 11). При обследовании этого поселения 24.06.2018 нами были обнаружены не более 3-4 заселённых семьями сурчин. Только 2-3 из них были довольно обширны, хорошо расчищены и утоптаны зверьками, а остальные, хотя и посещались сурками, но были невелики по площади и имели небольшое количество норных входов.

Лишь на одной самой большой сурчине, располагавшейся в центре участка, в бинокль удалось наблюдать 2-3 зверьков, которые были очень осторожны, и при обнаружении наблюдателей, даже на очень большом расстоянии, сразу же укрывались в норах.

Интересно размещение одной из сурчин на невысоком холме размером $20 \mathrm{\text {м }} \times 10 \mathrm{м}$, покрытом непролазными зарослями высоких трёхметровых колючих кустарников, под корнями которых сурками устроены норы. Эта сурчина практически не досягаема для людей и крупных хищников. Судя по всему, она существует многие десятилетия. Очевидно, что именно о ней упоминалось в работе В.Н. Александрова [1951]. 


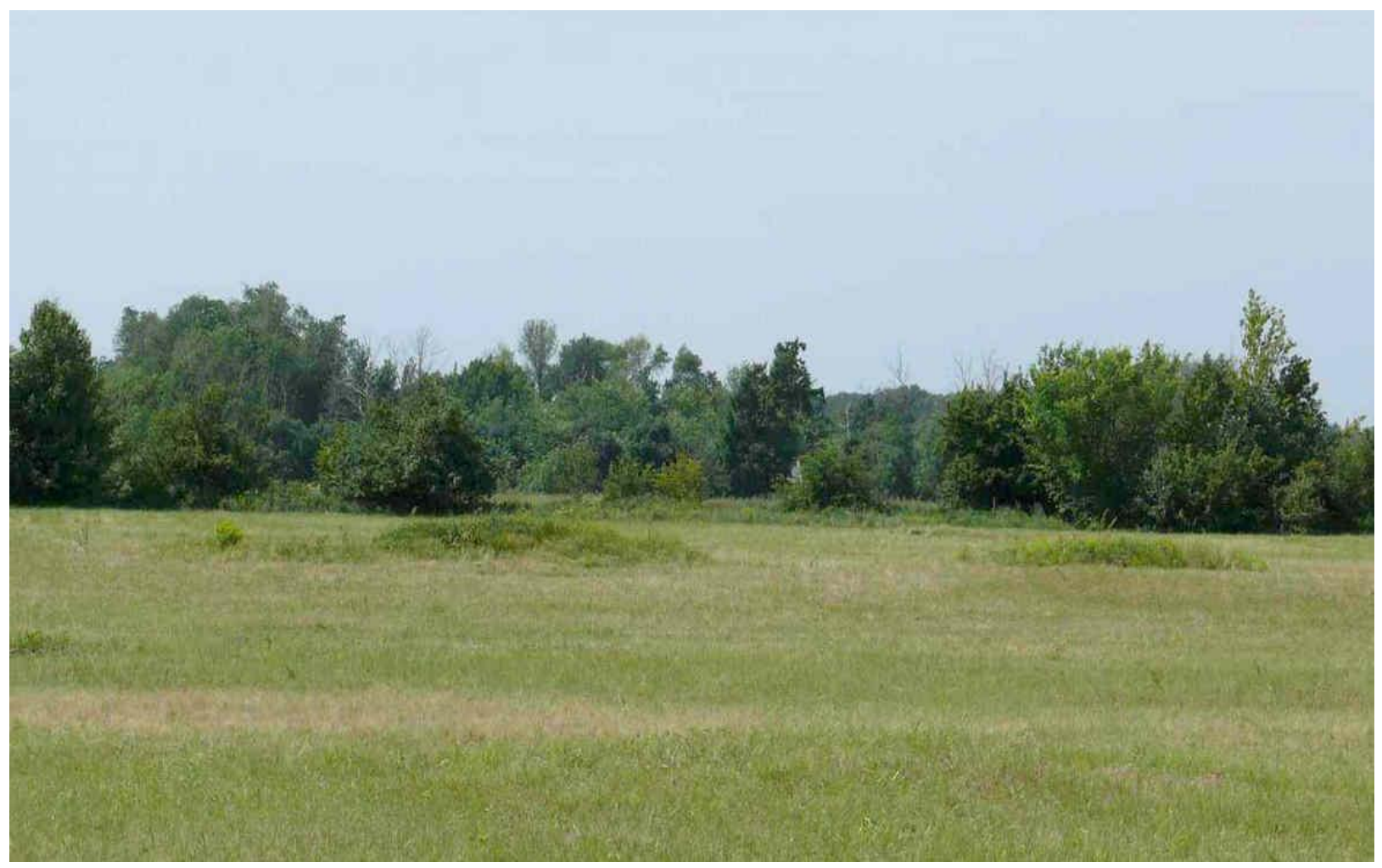

Рис. 11. Заповедный с 1885 г. участок залежной степи у северной окраины посёлка

2-го участка Научно-исследовательского института сельского хозяйства имени В.В. Докучаева.

Перед кустарниками видны две невысокие сурчины (фото А.С. Климова)

Fig. 11. Reserved since 1885 a plot of fallow steppe near northern vicinity of village of $2^{\text {nd }}$ section of Scientific Research Institute of Agriculture named after V.V. Dokuchaev.

Two marmot burrows are visible in front of bushes (photo by A. Klimov)

Автор отмечал, что на этих холмах плотность населения сурков была очень значительна - 17 жилых нор с общим числом населявших их зверьков приблизительно в 40 особей на общей площади в 1 га. Правда, в описании нет упоминания о зарослях кустарников, которых в то время, по-видимому, ещё не было [Александров, 1951].

Обследование поселения в 2019 г. показало, что зверей в поселении осталось немного. И хотя многие норы были со следами явного посещения, но большинство из них использовались сурками неактивно, некоторые были сильно заросшие растительностью. Очевидно, что сурков остались единицы. В этот год не удалось увидеть ни одного зверя.

Судя по всему, это поселение, несмотря на многолетнее существование, обречено на постепенное угасание и скорое исчезновение. Этому способствует его достаточно долгая изоляция от других группировок байбаков и ограниченная возможность расселения изза отсутствия поблизости подходящих мест обитания, поскольку поселение на многие километры вокруг окружено пашнями, возделанными сельскохозяйственными полями, полезащитными лесными полосами и некосимыми залежными участками, где сурки, как правило, не селятся.

17. Castor fiber Linnaeus, 1758 - обыкновенный бобр.

Присутствие данного вида отмечено на левом берегу средней части Таловского пруда, где участки леса вплотную подходят к берегу. Судя по ряду косвенных признаков (сильно взмученной воде и большому количеству погрызов прибрежных кустов и деревьев), бобр здесь довольно обычен.

18. Spalax microphtalmus Güldenstaedt, 1770 - обыкновенный слепыш.

Обычный вид в Каменной степи. Характерные выбросы почвы из нор зверька сравнительно часто встречаются по обочинам дорог и на косимых участках. Такие выбросы 
нами встречались как на северной окраине посёлка у лесополосы № 138, так и южнее, на косимом участке у лесополосы № 40. Нередко зверёк проникает и в сам посёлок, прокапывая свои подземные ходы на заброшенных пустырях.

19. Ondatra zibethicus (Linnaeus, 1766) - ондатра.

Скорее всего, судя по наличию многочисленных подходящих для жизни биотопов, ондатра обычна на водохранилище и других водоёмах Каменной степи. Нами был встречен всего один зверёк этого вида. 23.06.2018 на водохранилище в течение нескольких минут нами наблюдалась в бинокль взрослая ондатра, которая, не торопясь, открыто переплывала по поверхности воды с одного берега на другой.

20. Myodes glareolus (Schreber, 1780) - европейская рыжая полёвка.

Наиболее многочисленный вид среди мелких млекопитающих, населяющих лесные полосы [Климов и др., 2020]. В старовозрастных полосах было отловлено 29 особей полёвок. Общая относительная численность данного вида составила 8,1 \% попаданий в ловушки. Зверьков чаще отлавливали в середине лесных полос. Относительная их численность здесь была в 11,3 раза выше, чем на опушках (16,9\%).

21. Sylvaemus flavicollis (Melchior, 1834) - желтогорлая мышь.

Занимает второе место по величине относительной численности в старых лесополосах. Всего было отловлено 13 желтогорлых мышей. Общая относительная численность этого вида была равна 3,4 \% попаданий в ловушки. Зверьки попадали в ловушки примерно одинаково часто как внутри полос, так и на их окраинах.

22. Sylvaemus uralensis (Pallas, 1811) - малая лесная мышь.

Третий по численности вид среди грызунов, составляющих основное население мелких млекопитающих лесных полос. Всего было добыто 11 зверьков. Соответственно, общая относительная численность вида была равна 3,1 \% попаданий в ловушки. Судя по отловам, лесные мыши придерживались опушек лесополос. Здесь их относительная численность (4,5\%) была в 3,5 раза больше, чем в середине полос.

23. Apodemus agrarius (Pallas, 1771) - полевая мышь.

Предпочитает селиться в открытых биотопах. Поэтому в лесополосах этот вид встречается гораздо реже всех остальных грызунов. Всего было поймано 7 зверьков этого вида. Относительная численность полевых мышей была равна 2,0 \%. Все отловленные зверьки были пойманы на опушках лесных полос.

\section{Заключение}

Относительная кратковременность наших наблюдений не позволяет сделать обобщающих выводов по динамике видового состава и численности наземных позвоночных Каменной степи в XXI в. Такую цель мы и не преследовали, публикуя данные наблюдения. Исследования необходимо продолжить. Тем не менее, можно с уверенностью говорить о присутствии на территории (акватории) Каменной степи 6 видов земноводных 2 отрядов, 4 видов пресмыкающихся 3 отрядов, 76 видов птиц 15 отрядов и 23 видов млекопитающих, относящихся к 3 отрядам.

Земноводные и пресмыкающиеся Каменной степи относительно редки. Как и по всей Воронежской области, здесь наиболее обычны из сухопутных амфибий зелёные жабы, а из полуводных - озёрные лягушки. Среди пресмыкающихся чаще всего встречаются прыткие ящерицы. Остальные виды обнаруживаются довольно редко, что, вероятно, объясняется относительной засушливостью здешнего климата.

Некоторые изменения произошли в видовом составе птиц лесных полос. Так, из лесополос исчезли многочисленные колонии грачей, которые, по данным В.Г. Турчина [2000], в середине 1990-х годов насчитывали 5 тысяч пар. Нами не обнаружено в лесополосах и 
гнёзд обыкновенной сороки, хотя выводки были встречены в районе водохранилища. Возможно, это явилось одним из факторов отсутствия в лесополосах гнездящихся ушастых сов, кобчика и пустельги. Численность обыкновенной пустельги находится на минимальном уровне (две встречи за два года). Следует отметить, что численность грача и сороки в последние 10-15 лет сократилась по всей территории Воронежской области [Нумеров, Венгеров, 2016; Венгеров, Нумеров, 2017]. Тесные взаимосвязи хищных птиц и сов с врановыми сложились исторически и хорошо известны [Турчин, 1994, 1996; Нумеров и др., 2007].

Совершенно очевидным стало увеличение в лесополосах количества видов птиц, использующих дупла и полудупла для устройства гнёзд. Это следствие естественного старения деревьев и увеличения среди них доли фаутных. Среди вторичных дуплогнёздников из воробьеобразных - это не менее 13 видов. Кроме того, многочисленной группой дуплогнёздников в лесополосах Каменной степи являются дятлы (не менее 4 видов), что также способствует ежегодному увеличению количества дупел.

Новыми гнездящимися видами, в сравнении со списком В.Г. Турчина [2000], стали серая цапля, белокрылая крачка, а также, с большой вероятностью, сирийский дятел и удод. В то же время не встречены во время наших наблюдений такие считавшиеся ранее обычными виды, как серая куропатка, фазан, коростель, чернолобый сорокопут и болотная камышёвка.

Новыми сведениями для территории Каменной степи являются материалы по рукокрылым. Это слабо изученная группа позвоночных в области. В списках А.А. Силантьева [1898] для Каменной степи летучие мыши отсутствуют, хотя приводятся для Хреновского бора и других мест. Единственный случай наблюдения летучей мыши (позднего кожана) в Каменной степи отмечен в 1935 г. [Барабаш-Никифоров, 1957]. Акустический мониторинг позволил установить пребывание на территории Каменной степи не менее 12 видов рукокрылых. Применение метода ультразвукового сканирования расширяет возможности фаунистических исследований, но в ряде случаев видовая принадлежность регистрируемых рукокрылых требует дополнительной проверки и идентификации с помощь специальных компьютерных программ и отлова.

\section{Благодарности}

Авторы выражают признательность за консультащии и помощьь в проведении полевых исследований научным сотрудникам Каменно-Степного опытного лесничества В.Д. Тунякину и Н.В. Рыбалкиной.

\section{Список литературы}

1. Александров В.Н. 1951. Материалы по биологии сурка-байбака в условиях Каменной степи Воронежской области. Курсовая работа. Воронеж, ВГУ, 70 с.

2. Барабаш-Никифоров И.И. 1957. Звери юго-восточной части Черноземного центра. Воронеж, Воронежское книжное издательство, 370 с.

3. Барабаш-Никифоров И.И., Александров В.Н. 1953. О состоянии стада сурков-байбаков Воронежской области. Бюллетень общества естествоиспытателей при Воронежском государственном университете, 8: 7-12.

4. Венгеров П.Д., Нумеров А.Д. 2017. Тенденции в динамике численности врановых в Воронежской области в текущем столетии. $B$ кн.: Экология врановых птиц в естественных и антропогенных ландшафтах Северной Евразии. Материалы Всероссийской научной конференции, посвященной 80-летию д.б.н., профессора В.М. Константинова. Казань, Олитех: 68-72.

5. Венгеров П.Д., Рубан А.А. 2011. Характеристика авифауны старовозрастных полезащитных лесных полос Каменной степи. Известия Воронежского государственного педагогического университета, 257: 93-98. 
6. Венгеров П.Д., Соколов А.Ю., Нумеров А.Д. 2019. Обыкновенная горлица Streptopelia turtur на юго-востоке центрального Черноземья (Воронежская область). Байкальский зоологический журнал, 3: 8-11.

7. Дунаев Е.А., Орлова В.Ф. 2017. Земноводные и пресмыкающиеся России. Атласопределитель. М., Фитон XXI, 328 с.

8. Кистяковский А.Б. 1936. Выяснение экономического значения птиц полезащитных лесных полос и закладка опыта по привлечению полезных видов. $B$ кн.: Итоги работы Всесоюзного института защиты растений за 1935 г. Л., ВАСХНИЛ: 54-59.

9. Климов А.С., Нумеров А.Д., Труфанова Е.И., Тунякин В.Д., Рыбалкина Н.В. 2020. Распределение и численность мелких млекопитающих старовозрастных лесных полос Каменной степи (Таловский район Воронежской области). $B$ кн.: Актуальные вопросы экологии и паразитологии. Материалы онлайн-конференции с международным участием, посвященной памяти д.б.н., профессора Л.Н. Хицовой (г. Воронеж, 21 мая 2020 г.). Воронеж, Цифровая полиграфия: 40-48.

10. Климов А.С., Химин А.Н. 2018. Нетопырь средиземноморский Pipistrellus kuhli (Kuhl, 1817). В кн.: Красная книга Воронежской области: в двух томах. Т. 2. Животные. Воронеж, Центр духовного возрождения Черноземного края: 407.

11. Коблик Е.А., Редькин Я.А., Архипов В.Ю. 2006. Список птиц Российской Федерации. М., Товарищество научных изданий КМК, 256 с.

12. Красная книга Воронежской области: в двух томах. 2018. Том 2. Животные. Ред. О.П. Негробов. Воронеж, Центр духовного возрождения Черноземного края, 448 с.

13. Куликова Л.В. 1971. Опыт сплошного картирования птичьего населения лесных полос Каменной степи. Дипломная работа. Воронеж, ВГУ, 183 с.

14. Литвинчук С.Н. 2008. Молекулярно-биохимические и цитогенетические аспекты микроэволюции у бесхвостых амфибий фауны России и сопредельных стран. $B$ кн.: Вопросы герпетологии. Материалы 3-го съезда Герпетологического общества им. А.М. Никольского. СПб.: $247-257$.

15. Марин С.Н. 1951. Материалы по экологии гнездящихся птиц полезащитных лесных полос Каменной степи. Дипломная работа. Воронеж, ВГУ, 63 с.

16. Нумеров А.Д., Венгеров П.Д. 2016. Кадастр птиц (Aves) Воронежской области: двадцать лет спустя. Вестник Тамбовского университета. Серия Естественные и технические науки, 21 (5): 1830-1835.

17. Нумеров А.Д., Венгеров П.Д., Сапельников С.Ф. Соколов А.Ю., Куприянов А.А. 2007. Пример образования многовидового поселения птиц в результате гнездостроительной деятельности врановых. B кн.: Экология врановых в естественных и антропогенных ландшафтах. Материалы VIII Международной конференции по врановым птицам. Москва-Ставрополь: 39-43.

18. Огнев С.И. 1947. Звери СССР и прилежащих стран (Звери Восточной Европы и Северной Азии). Т. 5. М.-Л., Изд-во АН СССР, 810 с.

19. Огнев С.И., Воробьев К.А. 1923. Фауна наземных позвоночных Воронежской губернии. М., Новая деревня, 254 с.

20. Павлинов И.Я., Лисовский А.А. (ред.). 2012. Млекопитающие России: систематикогеографический справочник. М., Товарищество научных изданий КМК, 604 с.

21. Сапельников С.Ф. 2010. Распределение хищных птиц и ворона в Каменной степи. $B$ кн.: Орнитология в Северной Евразии. Материалы XIII Международной орнитологической конференции Северной Евразии (г. Оренбург, 30 апреля - 6 мая 2010 г.). Оренбург: 283-284.

22. Северцов Н.А. 1950. Периодические явления в жизни зверей, птиц и гад Воронежской губернии. 2-е изд. (напечатано по изданию 1855 г.). М., АН СССР, 308 с.

23. Семаго Л.Л. 1954. К вопросу формирования орнитофауны полезащитных полос и межполосных участков. Труды Воронежского государственного университета, 60 (3): 54-59.

24. Семаго Л.Л. 1960. Орнитофауна комплекса полезащитных лесных полос и межполосных участков юго-востока Черноземного центра и пути повышения ее полезной роли. Автореф. дис. ... канд. биол. наук. Воронеж, 23 с.

25. Семаго Л.Л. 1970. Изменения в орнитофауне Каменной степи с 1955 по 1967 год. Сообщение 1. Труды Воронежского государственного университета, 79: 22-26. 
26. Силантьев А.А. 1898. Зоологические исследования на участках экспедиции лесного департамента 1894-1896 гг. СПб., 180 с.

27. Тунякина С.В. 1998. Орнитофауна полезащитных лесонасаждений Каменной степи. Дипломная работа. Воронеж, ВГУ, 51 с.

28. Турчин В.Г. 1991. Изучение питания обыкновенной пустельги в агроценозах. $B$ кн.: Материалы X Всесоюзной орнитологической конференции (г. Витебск, 17-20 сентября 1991 г.). Ч. 2. Минск, Навука і тэхніка: 255-257.

29. Турчин В.Г. 1994. Влияние параметров лесополос на расселение пернатых хищников. $B$ кн.: Фундаментальная и методическая подготовка будущего специалиста по экологии и охране природы. Тезисы докладов Российской научно-практической конференции. Ч. 1. Орел: 143-144.

30. Турчин В.Г. 1996. Использование пернатыми хищниками гнезд врановых в Каменной степи. В кн.: Экология и численность врановых птиц России и сопредельных государств. Материалы 4-го совещания по экологии врановых птиц. Казань: 100-102.

31. Турчин В.Г. 1999а. Регионально редкие виды птиц Каменной Степи. В кн.: Редкие виды птиц и ценные орнитологические территории Центрального Черноземья. Липецк: 52-54.

32. Турчин В.Г. 1999б. Фауна хищных птиц и сов каменной степи и ее исторические изменения. Беркут, 8 (2): 141-146.

33. Турчин В.Г. 2000. Аннотированный список видов весенне-летней орнитофауны Каменной Степи. Беркут, 9 (1-2): 1-8.

34. Турчин В.Г., Борискина Н.В. 1996. Питание ушастой совы в Каменной Степи. $B$ кн.: Матеріали II конференціі молодих орнітологів України. Чернівці: 181-185.

35. Eptesicus serotinus - Кожан поздний. Чужеродные виды на территории России. URL: http://www.sevin.ru/invasive/invasion/mammals/m_37.html (дата обращения: 10 января 2021).

36. Pipistrellus kuhli - Нетопырь средиземный. Чужеродные виды на территории России. URL: http://www.sevin.ru/invasive/invasion/mammals/m_36.html (дата обращения: 10 января 2021).

\section{References}

1. Aleksandrov V.N. 1951. Materials on the biology of the bobak marmot in the conditions of the Kamennaya Step' of the Voronezh region. Course work. Voronezh, VGU, 70 p. (in Russian).

2. Barabash-Nikiforov I.I. 1957. Animals of the southeastern part of the Black Earth Center. Voronezh, Voronezh book publishing house, 370 p. (in Russian).

3. Barabash-Nikiforov I.I., Aleksandrov V.N. 1953. On the condition of the herd of bobak marmots in the Voronezh region. Byulleten' obshchestva yestestvoispytateley pri Voronezhskom gosudarstvennom universitete, 8: 7-12. (in Russian).

4. Vengerov P.D., Numerov A.D. 2017. Tendentsii v dinamike chislennosti vranovykh v Voronezhskoy oblasti $\mathrm{v}$ tekushchem stoletii [Trends in the dynamics of the number of corvids in the Voronezh region in the current century]. In: Ekologiya vranovykh ptits $\mathrm{v}$ yestestvennykh $\mathrm{i}$ antropogennykh landshaftakh Severnoy Yevrazii [Ecology of corvids in natural and anthropogenic landscapes of Northern Eurasia]. Materials of the All-Russian Scientific Conference dedicated to the 80th anniversary of Doctor of Biological Sciences, Professor V.M. Konstantinov. Kazan, Olitekh: 68-72.

5. Vengerov P.D., Ruban A.A. 2011. Kharakteristika avifauny starovozrastnykh polezashchitnykh lesnykh polos Kamennoy stepi [Characteristics of the avifauna of the old-growth field-protective forest belts of the Kamennaya Step']. IzvestiaVoronezskogo gosudarstvennogo pedagogiceskogo universiteta, 257: $93-98$.

6. Vengerov P.D., Sokolov A.Yu., Numerov A.D. 2019. European Turtle Dove Streptopelia Turtur in the South-East of the Black Soil Region (Voronezh Region). Baikalskij zoologičeskij žurnal, 3 : 8-11. (in Russian).

7. Dunayev Ye.A., Orlova V.F. 2012. Amphibians and Reptiles of Russia. Atlas-Determinant. Moscow, Fiton+, 328 p. (in Russian).

8. Kistyakovskiy A.B. 1936. Elucidation of the economic value of birds in field-protective forest belts and establishment of experience in attracting useful species. In: The results of the work of the AllUnion Institute of Plant Protection in 1935. Leningrad, VASKHNIL: 54-59. (in Russian).

9. Klimov A.S., Numerov A.D., Trufanova Ye.I., Tunyakin V.D., Rybalkina N.V. 2020. Raspredeleniye i chislennost' melkikh mlekopitayushchikh starovozrastnykh lesnykh polos Kamennoy Stepi (Talovskiy rayon Voronezhskoy oblasti) [Distribution and number of small mammals of old-growth 
forest belts of the Kamennaya Step' (Talovsky district of the Voronezh region)]. In: Aktual'nyye voprosy ekologii i parazitologii [Topical issues of ecology and parasitology]. Materials of an online conference with international participation dedicated to the memory of Doctor of Biological Sciences, Professor L.N. Khitsova (Voronezh, 21 May 2020). Voronezh, Tsifrovaya poligrafiya: 40-48.

10. Klimov A. S., Himin A. N. 2018. Bat mediterranean Pipistrellus kuhli (Kuhl, 1817). In: Red Data Book of the Voronezh Region: in two volumes. Vol. 2. Animals (Negrobov O.P., ed.). Voronezh, Tsentr dukhovnogo vozrozhdeniya Chernozemnogo kraya: 407.

11. Koblik E.A., Redkin Ya.A., Arkhipov V.Yu. 2006. List of Birds of the Russian Federation. Moscow, KMK Scientific Press Ltd., 256 p. (in Russian).

12. Red Data Book of the Voronezh Region: in two volumes. 2018. Vol. 2. Animals (Negrobov O.P., ed.). Voronezh, Tsentr dukhovnogo vozrozhdeniya Chernozemnogo kraya, 448 p. (in Russian).

13. Kulikova L.V. 1971. An experience of continuous mapping of the avian population of the forest belts of the Kamennaya Step'. Thesis. Voronezh, VGU, 183 p. (in Russian).

14. Litvinchuk S.N. 2008. Molekulyarno-biokhimicheskiye i tsitogeneticheskiye aspekty mikroevolyutsii u beskhvostykh amfibiy fauny Rossii i sopredel'nykh stran [Molecular-biochemical and cytogenetic aspects of microevolution in tailless amphibians of the fauna of Russia and neighboring countries]. In: Voprosy gerpetologii [Herpetology issues]. Materials of the 3rd Congress of the Herpetological Society. A.M. Nikolsky. Saint-Petersburg: 247-257.

15. Marin S.N. 1951. Materials on the ecology of nesting birds in the forest shelter belts of the Kamennaya Step'. Thesis. Voronezh, VGU, 63 p. (in Russian).

16. Numerov A.D., Vengerov P.D. 2016. Cadastre of Birds (Aves) of Voronezh Province: Twenty Years Later. Tambov University Reports. Series Natural and Technical Sciences, 21 (5): 18301835. (in Russian).

17. Numerov A.D., Vengerov P.D., Sapel'nikov S.F. Sokolov A.YU., Kupriyanov A.A. 2007. Primer obrazovaniya mnogovidovogo poseleniya ptits $\mathrm{v}$ rezul'tate gnezdostroitel'noy deyatel'nosti vranovykh [An example of the formation of a multi-species settlement of birds as a result of nest-building activities of corvids]. In: Ekologiya vranovykh v yestestvennykh i antropogennykh landshaftakh [Ecology of corvids in natural and anthropogenic landscapes]. Materials of the VIII International Conference on Corvids. Moscow - Stavropol: 39-43.

18. Ognev S.I. 1947. Animals of the USSR and adjacent countries (Animals of Eastern Europe and North Asia). Vol. 5. Moscow-Leningrad, Publishing House of the USSR Academy of Sciences, 810 p. (in Russian).

19. Ognev S.I., Vorob'yev K.A. 1924. Fauna of terrestrial vertebrates of the Voronezh province. Moscow, Novaya derevnya, 254 p. (in Russian).

20. Pavlinov I.Ya., Lisovskiy A.A. (eds.). 2012. Mammals of Russia: a systematic-geographical reference book. Moscow, KMK Scientific Press Ltd., 604 p. (in Russian).

21. Sapel'nikov S.F. 2010. Raspredeleniye khishchnykh ptits i vorona v Kamennoy stepi [Distribution of birds of prey and crows in the Kamennaya Step']. In: Ornitologiya v Severnoy Yevrazii [Ornithology in Northern Eurasia]. Materials of the XIII International Ornithological Conference of Northern Eurasia (Orenburg, 30 April - 6 May 2010). Orenburg: 283-284.

22. Severtsov N.A. 1950. Periodic phenomena in the life of animals, birds and reptiles of the Voronezh province. $2^{\text {nd }}$ ed. (printed from the 1855 edition). Moscow, USSR Academy of Sciences, $308 \mathrm{p}$. (in Russian).

23. Semago L.L. 1954. On the issue of avifauna formation in shelterbelts and interband areas. Trudy Voronezhskogo gosudarstvennogo universiteta, 60 (3): 54-59. (in Russian).

24. Semago L.L. 1960. The avifauna of the complex of field-protective forest belts and interband areas in the southeast of the Chernozem center and ways to increase its useful role. Abstract, diss. ... cand. biol. sciences. Voronezh, 23 p. (in Russian).

25. Semago L.L. 1970. Changes in the avifauna of the Kamennaya Step' from 1955 to 1967.

Message 1. Trudy Voronezhskogo gosudarstvennogo universiteta, 79: 22-26. (in Russian).

26. Silant'yev A.A. 1898. Zoological research on the sites of the expedition of the Forestry Department in 1894-1896. Saint-Petersburg, 180 p. (in Russian).

27. Tunyakina S.V. 1998. The avifauna of the field-protective forests of the Kamennaya Step'. Thesis. Voronezh, VGU, 51 p. (in Russian). 
28. Turchin V.G. 1991. Izucheniye pitaniya obyknovennoy pustel'gi v agrotsenozakh [Study of the nutrition of the common kestrel in agrocenoses]. In: Materials of the X All-Union Ornithological Conference (Vitebsk, September 17-20, 1991). Part 2. Minsk, Navuka i tekhnika: 255-257.

29. Turchin V.G. 1994. Vliyaniye parametrov lesopolos na rasseleniye pernatykh khishchnikov [Influence of the parameters of forest belts on the dispersal of birds of prey]. In: Fundamental'naya $\mathrm{i}$ metodicheskaya podgotovka budushchego spetsialista po ekologii i okhrane prirody [Fundamental and methodological training of a future specialist in ecology and nature protection]. Abstracts of the Russian scientific-practical conference. Part 1. Orel: 143-144.

30. Turchin V.G. 1996. Ispol'zovaniye pernatymi khishchnikami gnezd vranovykh v Kamennoy stepi [The use of corvids' nests by birds of prey in the Kamennaya Steppe]. In: Ekologiya i chislennost' vranovykh ptits Rossii i sopredel'nykh gosudarstv [Ecology and the number of corvids in Russia and neighboring countries]. Materials of the 4th meeting on the ecology of corvids. Kazan: 100-102.

31. Turchin V.G. 1999a. Regional'no redkiye vidy ptits Kamennoy Stepi [Regionally rare bird species of the Kamennaya Step']. In: Redkiye vidy ptits i tsennyye ornitologicheskiye territorii Tsentral'nogo Chernozem'ya [Rare bird species and valuable ornithological territories of the Central Black Earth Region]. Lipetsk: 52-54.

32. Turchin V.G. 1999b. Fauna of Birds of Prey and Owls of the Stone Steppe and Its Historical Changes. Berkut, 8 (2): 141-146. (in Russian). Russian).

33. Turchin V.G. 2000. Review of Bird Species of the Stone Steppe. Berkut, 9 (1-2): 1-8. (in

34. Turchin V.G., Boriskina N.V. 1996. Pitaniye ushastoy sovy v Kamennoy Stepi [Eating a longeared owl in the Kamennaya Step']. In: Proceedings of the II Conference of Young Ornithologists of Ukraine. Chernivtsi: 181-185.

35. Eptesicus serotinus - Late Kozhan. AlMS (Alien mammal Species). Alien species of mammals in the ecosystems of Russia. Available at: http://www.sevin.ru /invasive/invasion/mammals/m_37.html (accessed 10 January 2021) (in Russian).

36. Pipistrellus kuhli - Bat mediterranean. AlMS (Alien mammal Species). Alien species of mammals in the ecosystems of Russia. Available at: http://www.sevin.ru/invasive/invasion /mammals/m_36.html (accessed 10 January 2021) (in Russian).

\section{ИНФОРМАЦИЯ ОБ АВТОРАХ}

Нумеров Александр Дмитриевич, доктор биологических наук, доцент, профессор кафедры зоологии и паразитологии Воронежского государственного университета, г. Воронеж, Россия

Климов Александр Сергеевич, кандидат биологических наук, доцент, доцент кафедры зоологии и паразитологии Воронежского государственного университета, г. Воронеж, Россия

Труфанова Елена Ивановна, кандидат биологических наук, доцент, доцент кафедры зоологии и паразитологии Воронежского государственного университета, г. Воронеж, Россия

\section{INFORMATION ABOUT THE AUTHORS}

Numerov Alexander D., Doctor of Biological Sciences, Professor, Professor of the Department of Zoology and Parasitology of Voronezh State University, Voronezh, Russia

Klimov Alexander S., Candidate of Biological Sciences, Associate Professor, Associate Professor of the Department of Zoology and Parasitology of Voronezh State University, Voronezh, Russia

Trufanova Elena I., Candidate of Biological Sciences, Associate Professor, Associate Professor of the Department of Zoology and Parasitology of Voronezh State University, Voronezh, Russia 